\title{
Anna Zorska* \\ WSPÓŁCZESNA GLOBALIZACJA: PRZEBIEG, CZYNNIKI I OZNAKI METAMORFOZY PROCESU
}

\section{Od autorki}

Artykuł ten dedykuję wszystkim Pracownikom Kolegium Ekonomiczno-Społecznego SGH, dziękując za obdarzenie mnie życzliwością i wsparciem w czasie mojej wieloletniej pracy w Szkole Głównej Handlowej.

Skutki kryzysu w okresie 2008-2009 i spowolnienia wzrostu ekonomicznego w następnych latach na świecie są przedmiotem badań i ocen, a wiele $z$ nich dotyczy procesu globalizacji. Ważnym wątkiem analiz prowadzonych przez zachodnich ekonomistów są próby ustalenia kluczowych elementów, charakteru i trwałości przemian dokonujących się obecnie w procesie globalizacji. Badania opinii publicznej w różnych krajach wskazują na wyraźne pogorszenie się ocen i nastroju społeczeństwa w odniesieniu do globalizacji, którą uznaje się za przyczynę niekorzystnych zmian ekonomicznych i innych.

Zachodzące przemiany w przebiegu globalizacji można określić jako metamorfozę tego procesu. Chodzi o to, że w ramach (wewnątrz) globalizacji dokonują się przekształcenia, których konsekwencją może być zapoczątkowanie przejścia tego procesu do kolejnego, trzeciego etapu. Najbardziej znaczące elementy zmian w globalizacji dotyczą przekształceń w czynnikach i mechanizmach tego procesu, jak tė̇ w działalności podmiotów oraz w ich relacjach. Kompleks tych przeobrażeń przypuszczalnie ukształtuje nową charakterystykę globalizacji, a także zmieni jej skutki ekonomiczne, społeczne i polityczne w przyszłości.

Celem artykułu jest przedstawienie procesu globalizacji ewoluującego w ostatniej dekadzie, a przede wszystkim omówienie zasadniczych zmian dokonujących się w działaniu czynników i podmiotów kształtujących ten proces. Ustalenie zmian w czterech grupach czynników globalizacji pozwoli nie tylko pogłębić zrozumienie obecnych tendencji w gospodarce światowej, ale może też ujawnić oznaki metamorfozy

* Emerytowany pracownik Kolegium Ekonomiczno-Społecznego, Szkoła Główna Ilandlowa w Warszawie. 
globalizacji w przyszłości. Ich omówienie stanowi ważne zadanie badawcze i część tego artykułu. Co istotne, wskazanie obszarów ważnych przekształceń w globalnej gospodarce może skłonić do myślenia o potrzebnych zmianach w różnych dziedzinach polityki państwa, w kwestiach wspólnych dla aktywności i dobrobytu wszystkich ludzi.

Wskazane zagadnienia będą analizowane w trzech zasadniczych punktach artykułu. W punkcie 1 omówiono główne tendencje zmian w przebiegu globalizacji od roku 2008. W punkcie 2 przeanalizowano zmiany czynników globalizacji w następujących grupach: czynniki technologiczne, ekonomiczne, społeczno-demograficzne oraz polityczne. Punkt 3 został poświęcony skutkom i współzależności przemian w czynnikach, mechanizmach i podmiotach globalizacji oraz ocenie tych przemian jako oznak metamorfozy procesu globalizacji. Metamorfoza współczesnej globalizacji - będącej jednym $z$ wiodących procesów ekonomicznych - będzie oddziaływać na dalszy rozwój gospodarek krajów i świata.

\section{Przebieg globalizacji i zjawiska w tym procesie od czasu kryzysu 2008-2009}

Znaczenie globalizacji dla prowadzonej w danym czasie działalności gospodarczej polega przede wszystkim na tym, że w rezultacie tego procesu kompleksowo zmieniają się uwarunkowania rozwojowe dla przedsiębiorstw, gałęzi przemysłu i usług, gospodarek oraz społeczeństwa. Stopniowo narasta potrzeba zmian (dostosowań) w działalności różnych podmiotów do zewnętrznych uwarunkowań w globalnym otoczeniu. W dłuższym okresie implikuje to kolejną „falę" przemian w gospodarce światowej oraz formowanie się zmienionej charakterystyki globalizacji. Współzależność dokonujących się przemian skłania do analizy tendencji na róźnych płaszczyznach, a najważniejsze wydają się: procesowa (ewoluujący przebieg globalizacji), czynnikowa (siły kształtujące proces) oraz podmiotowa (głównie aktywność korporacji transnarodowych, państw, organizacji międzynarodowych).

\subsection{Globalizacja a gospodarczy kryzys i spowolnienie 2008+}

Ze względu na różne sposoby definiowania globalizacji ekonomicznej należy uściślić, że w najczęściej stosowanym ujęciu jest to proces, który odnosi się do umiędzynarodowienia działalności gospodarczej (biznesu) i wywodzi się z działalności przedsiębiorstw na rynkach zagranicznych. Według koncepcji P. Dickena globalizacja 
stanowi wyższy, bardziej złożony i zaawansowany etap aktywności zagranicznej na wszystkich poziomach gospodarowania: przedsiębiorstw, sektorów i regionów oraz gospodarek krajowych ${ }^{1}$. Zasadniczym skutkiem narastania tej aktywności jest integrowanie (łączenie, scalanie) działalności gospodarczej ponad granicami państw oraz tworzenie współzależności ekonomicznych w wymiarze globalnym² ${ }^{2}$ Integracja ponadgraniczna dokonuje się wskutek intensyfikacji przepływów i pogłębiania się powiązań o charakterze handlowym (obejmującym towary), inwestycyjnym (kapitały), kooperacyjnym (alianse i inne umowy) oraz informacyjnym (głównie przez sieci informacyjne) $)^{3}$. Proces globalizacji postępuje dzięki działaniu następujących grup czynników: postępu naukowo-technicznego, czynników ekonomicznych, społecznych i politycznych. Działanie tych czynników jest wzajemnie powiązane i interakcyjne, a zasadnicze znaczenie współcześnie odgrywa postęp w zakresie tworzenia i stosowania nowych technologii (informacyjnych i innych) ${ }^{4}$. Od strony podmiotowej sily napędowe procesu globalizacji są generowane przede wszystkim przez korporacje transnarodowe - KTN (ich ekspansję zagraniczną) oraz państwa narodowe i organizacje międzynarodowe (ich politykę zorientowaną na stosunki gospodarcze krajów i funkcjonowanie rynku). Polityka ekonomiczna o charakterze neoliberalnym spowodowała wzmocnienie w gospodarce światowej mechanizmów wolnego rynku oraz silne zwiększenie roli wielkich banków i międzynarodowych instytucji, jak też szybkie rozszerzanie się ponadgranicznego biznesu i sieci korporacji transnarodowych ${ }^{5}$. Takie czynniki, podmioty i mechanizmy przyczyniły się do postępu globalizacji na drugim etapie rozwoju tego procesu, tzn. trwającym od końca lat $80 .{ }^{6}$ W tym okresie utrzymywała się ekonomiczna i technologiczna dominacja Triady

1 P. Dicken, Global Shift. Internationalization of Economic Activity, The Guilford Press, New York-London 1992, s. 1 .

2 Wśród wielu publikacji na ten temat można wymienić m.in. prace prominentnych autorów: J.H. Dunning, The Globalization of Business. The Challenge of the 1990s, Routledge, London-New York 1993, s. VII; J. Bhagwati, In Defence of Globalization, Oxford University Press, New York 2004, s. IX; J.E. Stiglitz, Globalizacja, Wydawnictwo Naukowe PWN, Warszawa 2004, s. 26.

3 Integrowanie gospodarek ponad granicami państw dzięki przeplywom i powiązaniom ekonomicznym, jako istotę procesu globalizacji w sferze ekonomicznej, przyjęli m.in. następujący badacze: J.H. Dunning, D. IJeld, D. Baker, M. Wolf, J. Bhagwati, a także B. Liberska, G.W. Kołodko, A. Zorska.

4 Zachodzace obecnie zmiany w zakresie oddzialywania wskazanych czynników na proces globalizacji będą omówione w punkcie 2 artykułu.

5 A. Zorska, Ku globalizacji? Przemiany $w$ korporacjach transnarodowych $i w$ gospodarce swiatowej, Wydawnictwo Naukowe PWN, Warszawa 1998, s. 20.

6 Dominuje opinia, że pierwszy etap procesu globalizacji miał miejsce w dobie szybkiego rozwoju gospodarki kapitalistycznej oraz międzynarodowych przepływów towarów, kapitału i ludności w drugiej połowie XIX w. Ten etap globalizacji zakończył się wraz z wybuchem I wojny światowej w $1914 \mathrm{r}$. Są też inne opinie (mniej rozpowszechnione) mówiące, że globalizację zapoczątkowały wielkie odkrycia geograficzne i rozwój wymiany między kontynentami pod koniec $\mathrm{XV}$ w. Jednak w tym czasie rozwój wymiany międzynarodowej w niewielkim stopniu prowadzil do integrowania dzialalności gospodarczej (biznesu) na różnych poziomach, a jednocześnie ponad granicami państw. 
- grupy krajów będących „rdzeniem” procesu globalizacji - którą tworzyły US $\Lambda$, Europa Zachodnia oraz Japonia. Dokonał się dynamiczny rozwój krajów nowo uprzemysłowionych, głównie w Azji (Korea Południowa, Singapur, Hongkong, Tajwan). Wyłoniła się grupa krajów dokonujących systemowej transformacji - przede wszystkim Europa Środkowa i Wschodnia oraz Chiny - co umocniło postęp globalizacji i stworzyło nowe możliwości awansu ekonomicznego tych krajów.

Przedstawienie przebiegu globalizacji w dłuższym okresie nie jest możliwe w ramach ograniczonej objętości niniejszego artykułu, toteż będą przedstawione najważniejsze trendy czy struktury oraz dostępne wyniki badań oraz oceny. Istotne wydaje się wskazanie zasadniczych tendencji zmian w procesach i zjawiskach leżących u podstaw ewoluującej globalizacji, a $z$ drugiej strony - ujawnienie niektórych skutków tego procesu w ostatnich latach.

Nagłe zahamowanie postępu globalizacji na drugim etapie tego procesu nastąpiło wskutek wielkiego kryzysu finansowego, który został zapoczątkowany w 2007 r., a najsilniej rozwinął się w latach 2008-2009. Systemowe powiązania w bankowości oraz innych dziedzinach finansów, rozwój stosowania instrumentów pochodnych, wysoki stopień umiędzynarodowienia sektora finansowego, globalne przepływy kapitału oraz inne zjawiska przyczyniły się do wybuchu największego od lat 30. kryzysu w całej sferze finansów. Skalę kryzysu najlepiej wyraża jeden wskaźnik: w stosunku do roku 2007 ponadgraniczne przepływy kapitału na świecie zmniejszyły się o blisko $80 \%$, a w roku 2012 ich poziom podniósł się do około $60 \%$ wcześniejszej wartości . Wielki spadek globalnych przepływów kapitału pociągnął za sobą dramatyczne pogorszenie się sytuacji wielu banków i innych instytucji finansowych, ograniczenie podaży pożyczek, spadek kursów papierów wartościowych, wahania kursów walutowych, perturbacje w międzynarodowej wymianie i płatnościach dewizowych oraz szereg innych bardzo niekorzystnych zmian ${ }^{8}$.

Dynamikę zmian w gospodarce światowej w okresie 2008+ przedstawia tabela 1.

Wysoko zagregowane stopy wzrostu zamieszczone w tabeli 1 niedokładnie ilustrują kryzysowe perturbacje w gospodarce światowej. Przebieg kryzysu był dużo ostrzejszy w krajach rozwiniętych (USA, Europa Zachodnia) niż w gospodarkach transformujących się (Europa Środkowa, Chiny) i niektórych rozwijających się (Indie).

7 Według obliczeń McKinsey Global Institute w opracowaniu: Financial Globalization; Retreat or Reset?, Mc Kinsey Company, March 2013, s. 4, rys. E2.

8 Przebieg i skutki kryzysu 2008 zostały przedstawione m.in. w następujących publikacjach: J.E. Stiglitz, M. Guzman, Contemporary Issues in Macroeconomics: Lesson from the Crisis and Beyond, Palgrave-MacMillan, Basingstoke-New York 2016; M. Iwanicz-Drozdowska, Restrukturyzacja banków w Unii Europejskiej w czasie globalnego kryzysu finansowego, Oficyna Wydawnicza SGII, Warszawa 2015; Kryzys gospodarczy $2008+$ test dla stosowanej polityki. Metody przeciwdzialania i ich skutecznośc, red. K. Zukrowska, Oficyna Wydawnicza SGH, Warszawa 2013. 
Jako uzupełnienie danych z tabeli 1 można podać tzw. indeks głębokości globalizacji (depth index of globalization), wskazujący na umiędzynarodowienie krajowych gospodarek i uczestnictwo krajów w globalizacji. Wskaźnik ten obniżył sięze 117\% w 2007 r. (przyjmując poziom $2005=100 \%$ ) do $107 \%$ w 2009 r., co wyraża duży spadek wartości strumieni handlu oraz inwestycji bezpośrednich, jak też pogorszenie się innych parametrów ekonomicznych w czasie omawianego kryzysu. W roku 2012 indeks nadal utrzymywał się poniżej najwyższego wskaźnika i wynosił $114 \%{ }^{10}$. Ponieważ od roku 2012 handel międzynarodowy wzrasta nieco bardziej dynamicznie niż globalny PKB, zatem możliwe jest zbliżenie się wskaźnika głębokości globalizacji do poziomu $z 2007 \mathrm{r}$. W oparciu o te i inne informacje można szacunkowo przyjąć, że od czasu kryzysu 2008-2009 nastąpiło ogólne spowolnienie procesu globalizacji, towarzyszące stosunkowo niskiej aktywności w gospodarce światowej ${ }^{11}$.

Tabela 1. Tempo wzrostu PKB na świecie, nakładów inwestycyjnych, handlu, zatrudnienia i strumieni napływu zagranicznych inwestycji bezpośrednich w latach 2008-2016

\begin{tabular}{|l|r|r|r|r|r|r|r|r|r|}
\hline \multicolumn{1}{|c|}{ Kategoria } & 2008 & 2009 & 2010 & 2011 & 2012 & 2013 & 2014 & $2015^{\mathrm{a}}$ & $2016^{\mathrm{a}}$ \\
\hline Produkt krajowy brutto (PKB) & 1,5 & $-2,0$ & 4,1 & 2,9 & 2,4 & 2,5 & 2,6 & 2,8 & 3,1 \\
\hline Handel międzynarodowy & 3,0 & $-10,6$ & 12,6 & 6,8 & 2,8 & 3,5 & 3,4 & 3,7 & 4,7 \\
\hline $\begin{array}{l}\text { Naklady inwestycyjne brutto na środki } \\
\text { trwale }\end{array}$ & 3,0 & $-3,5$ & 5,7 & 5,5 & 3,9 & 3,2 & 2,9 & 3,0 & 4,7 \\
\hline Zatrudnienie & 1,2 & 1,1 & 1,2 & 1,4 & 1,4 & 1,4 & 1,3 & 1,3 & 1,2 \\
\hline Zagraniczne inwestycje bezpośrednie & $-20,4$ & $-20,4$ & 11,9 & 17,7 & $-10,3$ & 4,6 & $-16,3$ & 11,4 & $-13,2$ \\
\hline
\end{tabular}

a Dane szacunkowe.

Źródło: UNCTAD, World Investment Report 2015: Reforming International Investment Governance, New York-Geneva 2015, s. 2, tab. I. 1 oraz „Global Investment Trends Monitor” April 2017, s. 1, tab. 1; http://unctad.org/ en/PublicationsLibrary/webdiaeia2017d1_en.pdf [dostęp 6.04.2017].

Dzięki wielu zdecydowanym posunięciom rządów i międzynarodowych organizacji przeciwdziałającym kryzysowi w 2010 r. nastąpiło zahamowanie kryzysowych tendencji. Jednak odbudowanie większej aktywności gospodarczej nadal pozostaje trudnym zadaniem, na co wskazują dane zawarte w tabeli 1. Okres lat 2011-2016

9 Indeks został zaprezentowany w publikacji: P. Ghemawat, S.A. Altman, Depth Index of Globalization and the Big Shift to Emerging Economies, IESE Business School-University of Navarra, Barcelona-New York 2013. Autorzy przebadali 12 kategorii statystycznych, charakteryzujących powiązania międzynarodowe poszczególnych oraz wszystkich krajów łącznie, obliczając trzyletnie kroczące średnie dla tych kategorii.

10 Ibidem, s. 13, wyk. I.1.

11 Ocena ta znajduje potwierdzenie i uzasadnienie w najnowszych publikacjach: F. Hu, M. Spence, Why Globalization Stalled and How to Restart It, „Foreign Affairs” July/August 2017, s. 54-63; P. Ghemawat, Globalization in the Age of Trump, „Harvard Business Review” July/August 2017, s. 114-116 i n. 
charakteryzuje się stosunkowo słabą dynamiką wzrostu we wszystkich kategoriach ekonomicznych, przy czym silne wahania i duże ujemne stopy wzrostu występują tylko w przypadku strumieni naplywu ZIB (np. w latach 2012, 2014, 2016). Wstępne szacunki wzrostu gospodarczego na świecie w roku 2016 i na lata 2017-2018 nie są korzystne, gdyż zakładana jest dynamika nieprzekraczająca $2 \%$ w krajach rozwiniętych i wynosząca około $4,5 \%$ w krajach rozwijających się, w tym około $6 \%$ w Chinach ${ }^{12}$. Nie tylko niska aktywność w gospodarce, ale też malejąca dynamika wzrostu wydajności ma miejsce w krajach rozwiniętych. W okresie 1990-2014 dynamika wydajności w wiodących, rozwiniętych krajach G-7 lącznie obniżyła się $z+1,0 \%$ rocznie do $-1,0 \%$, przy czym wskaźniki są bardziej niekorzystne dla UE niż dla USA ${ }^{13}$. Rosną obawy o dlugofalowe spowolnienie wzrostu oraz o niedostateczny wpływ rewolucji technologicznej na dynamikę i strukturę gospodarki światowej. Nowe technologie nie wpłynęły silniej na odbudowę globalnej aktywności ekonomicznej po kryzysie 2008-2009 ${ }^{14}$. Wykorzystanie ekonomicznego potencjału wiedzy, nowych technologii, innowacji jest obecnie bardzo ważne dla aktywizacji wzrostu gospodarczego i wymaga wsparcia przez politykę państwa.

Co istotne, znacząco zmienił się stosunek społeczeństwa do globalizacji, nawet w krajach rozwiniętych ${ }^{15}$, gdzie ludzie uznali omawiany proces za przyczynę negatywnych zmian, jak np. bezrobocie, obniżka płac, nierówności dochodowe i społeczne. Aktywizują się działania antyglobalistów i przeciwników otwarcia gospodarek, a politycy odwracają się od projektów dalszej liberalizacji wymiany gospodarczej na świecie. Polityczne poparcie dla zmian ograniczających postęp globalizacji rośnie w wielu krajach, z wyjątkiem Chin.

\subsection{Zmiany globalnych strumieni eksportu i inwestycji bezpośrednich}

Dla ustalenia ogólnych tendencji do integrowania działalności gospodarczej na świecie zasadnicze znaczenie mają zmiany dynamiki i struktury przepływów towarów i czynników wytwórczych. Analizowane są przede wszystkim strumienie handlu międzynarodowego oraz zagranicznych inwestycji bezpośrednich (ZIB). Szczególnie ważne znaczenie mają przepływy ZIB, jako tzw. pakiet inwestycyjny

12 IMF, „World Economic Outlook” April 2017, s. 2, tab. 1.1, s. 46, aneks tab. 1.1.1, http://www.imf.org/ en/Publications/WEO/Issues/2017/04/04/world-economic-outlook-april-2017 [dostęp 24.05.2017].

13 G. Erber, U. Fritsche, P.Ch. Harms, The Global Productivity Slowdown: Diagnosis, Causes and Remedies, „Intereconomics” No. 1, 2017, s. 48, rys. 5.

14 World Bank, World Development Report 2016: Digital Dividends, World Bank Group, Washington 2016, s. 2

15 Badania wykazaly, że pod koniec 2016 r. mniej niż połowa Amerykanów, Brytyjczyków i Francuzów uważała, że globalizacja jest „czynnikiem zmian na lepsze”. Por. F. Hu, M. Spence, op.cit., s. 55-56. 
(kapitał, technologie, kadry, metody biznesowe), mające silne działanie integrujące firmy, przemysły i gospodarki ponad granicami państw.

Kryzysowe załamanie handlu międzynarodowego nastąpiło w 2009 r. i wyrażało się spadkiem wartości światowego eksportu o 22,5\% w stosunku do poprzedniego roku. Wzrost wywozu o 16,2\% nastąpil już w roku 2010, a następnie o 19,4\% w 2011 r., znacznie przekraczając poziom eksportu sprzed kryzysu ${ }^{16}$. W ostatnich latach tempo wzrostu światowego eksportu pozostawało niskie i wynosiło niewiele ponad 2\% w okresie 2012-2015, a na 2016r. WTO przewiduje wzrost zaledwie o $1,7 \%{ }^{17}$. Osłabienie dynamiki handlu międzynarodowego na świecie wynika $z$ wielu przyczyn, m.in. stosunkowo słabego wzrostu gospodarczego $w$ wielu krajach, wdrożenia instrumentów ograniczających import (przez niektóre kraje) ${ }^{18}$, silnych wahań kursów walutowych, napięć geopolitycznych, jak też mniej sprzyjającego klimatu politycznego dla wymiany handlowej.

W okresie 2009-2014 odbudowa wartości eksportu postępowała nierównomiernie na świecie, tzn. była wolniejsza w krajach wysoko rozwiniętych niż rozwijających się i transformujących się, a odpowiednie wskaźniki wynoszą 5,2\%, wobec $17,5 \%$. W konsekwencji udział krajów rozwiniętych w globalnym eksporcie obniży się z 55,4\% do 49,6\%. Oznacza to wzrost udziału krajów rozwijających się i transformujących się do poziomu 50,4\% wartości światowego eksportu i przekroczenie połowy wartości transakcji w dostawach towarów ${ }^{19}$. Sukces ten jest głównie zasługą Chin, które prześcignęły Niemcy oraz USA, stając się największym eksporterem i osiągając udział 10,5\% światowego wywozu w 2010 r., a następnie $12,4 \%$ w 2014 r. ${ }^{20}$ W zmianach geograficznej struktury światowego eksportu dużą rolę odegrała grupa BRICS (w tym głównie Chiny), której udział zwiększył się z 15,0\% do 18,0\% w latach 2009-2013 ${ }^{21}$. Jednak wzrost pozycji w globalnym eksporcie jest nie tylko zasługą przedsiębiorstw z mniej rozwiniętej części świata, ale również zachodnich KTN. Ich globalne łańcuchy dostaw tworzyły $49 \%$ światowego handlu towarami i usługami

16 WTO, 2014 International Trade Statistics Yearbook, Vol. I, Geneva 2014, s. 4-14, tab. A, obliczenia własne.

17 https://www.wto.org/english/res_e/booksp_e/wtr15-1_e.pdf [dostęp 6.04.2017].

18 Wobec ograniczenia instrumentów protekcjonistycznych $w$ handlu międzynarodowym przez WTO nowe instrumenty antykryzysowe skierowane zostały „do wewnątrz” krajów podejmujących ochronę gospodarki i przedsiębiorstw krajowych. Poznaliśmy nowy termin „mikroprotekcjonizm”.

19 WTO, 2014 International Trade..., op.cit., s. 4-14, tab. A, obliczenia wlasne.

20 Ibidem.

21 I. Pawlas, Uczestnictwo państw BRICS w międzynarodowych obrotach towarowych, [w:] Panstwa grupy BRICS i ich znaczenie we wspótczesnej gospodarce światowej, red. T. Sporek, K. Czech, Wydawnictwo UE w Katowicach, Katowice 2015, s. 62-65, w tym tab. 4.4. Warto dodać, że w okresie 2001-2013 był to wzrost udziału BRICS z $8,0 \%$ do $18,0 \%$. 
(w 2011 r. ) $^{22}$. W dużej części korporacyjne łańcuchy dostaw są ulokowane w krajach rozwijających się, a dostawy wewnątrzkorporacyjne zaliczane są do eksportu kraju pochodzenia towarów ${ }^{23}$.

Struktura gałęziowa światowego eksportu towarów ewoluuje ku produktom wysokich technologii, co jest konsekwencją unowocześnienia produkcji pod wpływem dynamicznego postępu technologicznego, globalnego transferu technologii oraz modernizacji zasobów i zdolności wytwórczych w krajach rozwijających się. Chociaż eksporterami produktów zaawansowanych technologicznie są głównie kraje rozwinięte (na czele z USA), w grupie wiodących dostawców są też kraje azjatyckie. W 2014 r. Chiny wyeksportowały produkty wysokich technologii o wartości 558 mld USD, co dało im pozycję nr 1 wśród dostawców na świecie ${ }^{24}$. Należy zauważyć, że eksport ten ma duży „wkład” importowy, w postaci dostaw w ramach offshoringu przez zachodnie korporacje ${ }^{25}$. W rozwijającym się globalnym eksporcie usług również wzrasta znaczenie krajów mniej rozwiniętych, głównie z regionu Azji. Co istotne, dotyczy to także nowoczesnych usług, np. komputerowych i informacyjnych, których średnia dynamika wynosiła 18\% w ostatnim dwudziestoleciu. W latach 1995-2014 udział krajów azjatyckich - głównie Indii i Chin - zwiększył się z $8 \%$ do 29\% wartości światowego eksportu usług komputerowych i informacyjnych ${ }^{26}$. Przesunięcia w strukturze wywozu towarów i usług na świecie wskazują na znaczące zmiany w przewagach komparatywnych i tworzenie się nowych, zaawansowanych technologicznie specjalizacji eksportowych w niektórych krajach o niższym poziomie rozwoju niż państwa Triady.

Przepływy ZIB cechuje duża wrażliwość na impulsy kryzysowe w gospodarkach krajów i świata, toteż nastąpił duży spadek wartości strumieni inwestycyjnych w okresie 2008-2009 oraz wahania poziomu i dynamiki w dalszych latach spowolnienia gospodarczego. W latach 2008-2009 wartość strumienia napływu ZIB w skali światowej zmniejszyła się aż o 47\% (w stosunku do roku 2007), czyli prawie o połowę. W grupie krajów rozwiniętych strumień skurczył się o 60,7\%, a w grupie krajów rozwijających się i transformujących obniżył się o $15,4 \%$ we wskazanym okresie ${ }^{27}$.

22 WTO, 2015 International Trade Statistics Yearbook, Vol. I, Geneva 2015, s. 18.

23 W przypadku Chin około 60\% wartości eksportu maszyn i urządzeń tworzą dostawy realizowane przez zachodnie firmy i ich chińskie filie zagraniczne na rynek globalny.

24 https://knoema.com/atlas/ranks/High-technology-exports [dostęp 12.05.2017].

25 Najlepszym przykładem jest eksport smartfonów i komputerów osobistych. Tylko 15\% wartości tych urządzeń powstaje w Chinach, a kraj ten jest ich największym dostawcą na rynek globalny. Por. P. Ghemawat, Th. Hout, Can China's Companies Conquer the World? The Overlooked Importance of Corporate Power, „Foreign Affairs” March/April 2016, s. 92.

26 Ibidem, s. 20.

27 UNCTAD, World Investment Report 2010: Investing in a Low-carbon Economy, UN-UNCTAD, New York-Geneva 2010, s. 167-171, aneks tab. 1, obliczenia własne. 
Należy dodać, że w czasie załamania strumieni ZIB dodatnie wskaźniki napływu utrzymały tylko dwie duże gospodarki: Chiny (wzrost o $14,5 \%$ ) oraz Indie $(40 \%)^{28}$, a kraje BRIC jako grupa państw umocniły pozycję odbiorców kapitału zagranicznego ${ }^{29}$. Napływ obcego kapitału, technologii, kwalifikowanych kadr, udział w sieciach zbytu KTN stworzyły tym krajom - wraz z własnym wysiłkiem rozwojowym - możliwości przyspieszenia modernizacji gospodarek i eksportu.

Globalny strumień napływu ZIB (FDI inflow) wzrósł do 1.276 mld USD w $2014 \mathrm{r}$. i do 1.762 mld USD (wstępnie) w 2015 r., ale był to poziom znacznie poniżej rekordowej wartości 2.100 mld USD w $2007 \mathrm{r} .{ }^{30} \mathrm{~W}$ wyniku zróżnicowanej dynamiki strumieni napływu ZIB na świecie udział krajów rozwiniętych zmniejszył się z 68,8\% do 50,8\% w latach 2007-2009, a w kolejnych latach obniżył się do 40,9\% (w 2014 r.). W przypadku grupy krajów rozwijających się i transformujących odsetek globalnego strumienia napływu ZIB zwiększył się z 27,0\% do 43,1\% w latach 2007-2009, a następnie podniósł się do 59,1\% w 2014 r. W tym samym okresie łączny udział Chin i Hongkongu w światowym napływie omawianych inwestycji zwiększył się z 7,0\% do 23,6\%, a następnie osiągnął 17,6\% w 2014 r. Te dwa kraje - jako nieformalny chiński obszar gospodarczy - stały się największym odbiorcą ZIB na świecie, wyprzedzając USA i poszczególne kraje UE.

Duże zmiany nastąpiły też w okresie $2008+\mathrm{w}$ strumieniach odpływu ZIB (FDI outflow). W latach 2003-2014 kierunek zmian był podobny: udział krajów rozwiniętych malejący do 60,7\%, a udział krajów rozwijających się i transformujących się rosnący z 8,3\% do 39,3\% w 2014 r. W tym okresie udział Chin i Hongkongu zwiększył się z $1,0 \%$ do $18,8 \%{ }^{31}$. Większa odporność na kryzys, reformy ekonomiczne, modernizacja gospodarek w Chinach, Indiach i wielu krajach rozwijających się skutkują umacnianiem się ich znaczenia w odpływie ZIB, jak również rozwojem zagranicznej ekspansji przedsiębiorstw, które - stając się KTN - nabierają znaczenia na rynku globalnym.

Po okresie dramatycznego załamania w sektorze bankowym w latach 2007-2009 ustał silnie destabilizujący wpływ rynku finansowego na gospodarkę światową. Poprawa sytuacji była konsekwencją dużej pomocy udzielonej przez krajowe rządy

28 Ibidem. Wartość strumienia płynącego na rynek chiński była 8 razy większa niż na rynek indyjski w $2009 \mathrm{r}$.

29 K. Czech, Znaczenie państw BRICS w międzynarodowym transferze kapitalu na przykładzie bezpośrednich inwestycji zagranicznych, [w:] Pañstwa grupy BRICS i ich znaczenie we wspótczesnej gospodarce światowej, op.cit., s. 86, rys. 5.1, tab. 5.4.

30 UNCTAD, World Investment Report 2016. Investor Nationality: Policy Challenges, UN-UNCTAD, New York-Geneva 2010, s. 196-1199, aneks tab. 1, obliczenia wlasne.

31 UNCTAD, World Investment Report 2010..., op.cit., s. 167-171, aneks tab. 1, obliczenia wlasne; UNCTAD, World Investment Report 2016..., op.cit., s. 196-1199, aneks tab. 1, obliczenia wlasne. 
oraz międzynarodowe instytucje, a także zapoczątkowania wprowadzania na poziomie ponadnarodowym nowych regulacji, standardów, procedur działalności, rozszerzenia nadzoru bankowego, uruchomienia współpracy międzynarodowej dla załagodzenia skutków kryzysu. Globalna wartość transakcji finansowych obniżyła się i jest lepiej dostosowana do potrzeb działalności gospodarczej, chociaż elementy ryzyka w ekspansji banków nadal występują $a^{32}$. W trakcie tworzenia przez państwa G-20 oraz największe instytucje finansowe są podstawy nowej, globalnej architektury finansowej, która może w przyszłości zwiększyć stabilność i bezpieczeństwo bankowości na świecie ${ }^{33}$. Poważne zagrożenie globalne stanowią nierównowagi platnicze niektórych krajów, wynikające $z$ dysproporcji w obrotach handlowych (np. w relacjach USA i Chin) i kumulacji deficytów płatniczych. W przyszłości może to stwarzać napięcia w światowym systemie finansowym i zadecydować o nowych, restrykcyjnych posunięciach w zakresie polityki handlowej państw będących zadłużonymi potęgami gospodarczymi.

\subsection{Charakterystyka zmian w działalności KTN i relacjach grup podmiotów uczestniczących w globalizacji}

W procesie globalizacji dużą rolę odgrywa aktywność głównych grup podmiotów, którymi są: korporacje transnarodowe, państwa narodowe, organizacje międzynarodowe, organizacje pozarządowe. W długim okresie ewoluują te podmioty, ich zaangażowanie i relacje, jak też oddziaływanie na umiędzynarodowienie działalności gospodarczej. Drugi etap globalizacji cechował się silną ekspansją KTN w gospodarce światowej, co było powodem uznania działalności korporacji za główną „siłę napędową" omawianego procesu. Globalna ekspansja KTN była możliwa dzięki aktywnej, neoliberalnej polityce państw i organizacji międzynarodowych, które otwierały i usprawniały rynki (krajowe, globalny) oraz przyciągały napływ korporacyjnych ZIB w celu aktywizacji modernizacji goszczących gospodarek. Stopniowo jednak ujawnialy się negatywne skutki intensywnej konkurencji globalnej, penetracji i eksploatacji przez KTN goszczących je gospodarek, podatności krajów na tzw. szoki

\footnotetext{
32 Poziom przepływów kapitału i ich relacja do PKB na świecie pozostała niska w latach 2011-2015, wynosząc zaledwie 5,4\% globalnego PKB (według obliczeń McKinsey Institute). Istnieje potencjał wzrostu przepływów kapitału. Por. S. Mallaby, Globalization Resets, „Finance and Development” December 2016, s. 7.

33 B. Liberska, Globalna architektura finansowa po kryzysie. Regulacje $i$ wyzwania, [w:] Nowa architektura finansowa. W stronę bezpieczeństwa sektora bankowego, red. B. Liberska, Wydawnictwo UJ, Kraków 2016, s. $205-224$.
} 
zewnętrzne, przenoszenia prac $\mathrm{B}+\mathrm{R}$ i produkcji za granicę, oligopolizacji rynków, unikania opodatkowania przez korporacje itd. Z wielu powodów w niektórych krajach macierzystych (USA, Francja, Włochy) działalność KTN jest otwarcie krytykowana przez władze publiczne. Ogólnie, zmienił się klimat polityczny i społeczny dla działalności KTN. Zdaniem P. Ghemawata atak na globalizację jest też częściowo skierowany na korporacje ${ }^{34}$. Znaczenie ekspansji KTN dla przebiegu globalizacji nadal jest duze, co wynika $z$ ich dominującego udziału w międzynarodowych przepływach wyrobów, usług, czynników wytwórczych, wiodącej pozycji w wielu sektorach gospodarki i w nakładach na prace $\mathrm{B}+\mathrm{R}$, stosowania ponadgranicznych struktur i strategii, „osadzenia” zagranicznych filii i ośrodków badawczych w wielu krajach itd.$^{35}$ Koncentrując się na zmianach w działalności KTN w okresie 2008+, należy podkreślić, że wielki kryzys gospodarczy nie przyniósł duzego uszczerbku interesom korporacji (poza spadkiem przepływów ZIB) ${ }^{36}$. KTN (Zwłaszcza amerykańskie) szybko dokonały wielu dostosowań w biznesie. Jednakże kryzys i spowolnienie gospodarcze, zmiany na rynku globalnym, konieczność przebudowy globalnych łańcuchów dostaw, rozwój lokalnych przedsiębiorstw i nasilenie się ochrony krajowych gospodarek przyczyniły się do powstania niekorzystnych uwarunkowań dla globalnej ekspansji KTN.

W okresie 2008+ w globalnym zaangażowaniu KTN wystąpiły następujące nowe dostosowania lub pogłębiły się wcześniejsze tendencje w ich działalnoścỉi:

- „Przetasowanie” na liście największych na świecie pięciuset KTN: liczba chińskich KTN (193 firmy w 2015 r.) wzrosła silnie w ostatnich latach i przekroczyła liczbę korporacji pochodzących z UE (łącznie 197 firm), zblizając się do najliczniejszej grupy korporacji pochodzących z USA (193 firmy $)^{38}$.

34 P. Ghemawat, op.cit., s. 122. Ale z drugiej strony trzeba też przyznać, że korporacje „zapracowały” na niekorzystną opinię o skutkach globalizacji.

35 Szerzej na ten temat: A. Zorska, Korporacje transnarodowe. Przemiany, oddzialywania, wyzwania, PWE, Warszawa 2007 oraz raporty UNCTAD z serii „World Investment Report” (wydawane corocznie).

36 Relatywnie niezłą sytuację KTN w czasie kryzysu 2008-2009 ilustrują różne wskaźniki. Przykładowo, w stosunku do poziomu $z$ lat 2005-2007 wartość sprzedaży wyrobów i usług przez zagraniczne filie KTN w latach 2009, 2010, 2011 wzrastała odpowiednio o 18,9\%, 10,7\%, 10,9\% rocznie. Źródło: UNCTAD, World Investment Report 2010. Towards a New Generation of Investment Policies, UN-UNCTAD, New York-Geneva 2010, s. 25, tab. I.8, obliczenia wlasne.

37 UNCTAD, World Investment Report 2015. Reforming International Investment Governance, UN-UNCTAD, New York-Geneva 2016; UNCTAD, World Investment Report 2016. Investor Nationality: Policy Challenges, UN-UNCTAD, New York-Geneva 2010; A. Zorska, Korporacje transnarodowe a suwerenność panistwa. Kwestia relacji korporacje - państwo w dobie globalizacji, regionalizacji i rewolucji informacyjnej, [w:] Dokad zmierza Europa: państwo - gospodarka - społeczenistwo - finanse, red. J. Kleer, P. Szukalski, K. Prandecki, PAN, Komitet Prognoz „Polska 2000+”, Warszawa 2016, s. 144-173; P. Ghemawat, op.cit., s. 112-123; Multinationals: The Retreat of the Global Company, „The Economist” January 28, 2017; , The Economist”, http:// www.economist.com/news/briefing/21715653-biggest-business-... [dostęp 12.05.2017].

38 Global 500, „Fortune” August 1, 2016, s. F-1-F-20. 
- Restrukturyzacja i przebudowa (w części likwidacja) sieci zagranicznych filii oraz ośrodków badawczych KTN w skali globalnej, w dostosowaniu do zachodzących zmian ekonomicznych i politycznych na świecie.

- Szybszy wzrost produkcji, sprzedaży i eksportu przez korporacyjne filie zagraniczne niż wzrost PKB i eksportu na świecie. Wzrost relacji wartości dodanej wytworzonej przez zagraniczne filie korporacji do wartości PKB na świecie.

- Ogólne obniżenie znaczenia KTN, jako inwestorów lokujących ZIB w sferze produkcyjnej na świecie. Dotyczy to przede wszystkim zachodnich KTN, a w szczególności unijnych korporacji. Tymczasem wzrasta ranga (i wartość lokat ZIB) przedsiębiorstw pochodzących $z$ Chin oraz z innych krajów mniej rozwiniętych.

- Przesunięcie form ekspansji zagranicznej KTN od inwestycji (ZIB) do kooperacji i handlu międzynarodowego, co zwiększa możliwości międzynarodowego przenoszenia produkcji i oslabia „osadzenie” i wplywy zagranicznych firm w krajach goszczących.

- Wzrost znaczenia KTN w działalności badawczej na świecie, przy czym najbardziej dynamicznie rosną nakłady $\mathrm{B}+\mathrm{R}$ przez firmy azjatyckie, głównie pochodzące z Chin i Indii. Postępuje umiędzynarodowienie korporacyjnej działalności B+R.

- Nasilenie przez KTN działań o charakterze manipulacji podatkowej, polegających na ukrywaniu dochodów i niepłaceniu podatków oraz zacieraniu przynależności krajowej firmy inwestującej; transferowanie dochodów i zysków do „rajów podatkowych".

- Osłabienie globalnej ekspansji KTN działających w tradycyjnych gałęziach przemysłu, a intensyfikacja penetracji rynku globalnego przez korporacje działające w zaawansowanych technologicznie branżach (zwłaszcza nowoczesnych usługach $)^{39}$.

W porównaniu z dynamiką globalnej ekspansji na drugim etapie globalizacji obecna sytuacja KTN z tradycyjnych gałęzi przemysłu i usług uległa pogorszeniu. Świadczą o tym następujące zjawiska: obniżenie zyskowności z produkcji międzynarodowej (na tle produkcji i inwestycji krajowych) w korporacjach zachodnich i azjatyckich, kurczenie się możliwości arbitrażowania (np. wskutek mniejszej różnicy płac czy stawek podatkowych), zwiększenia konkurencji ze strony lokalnych dostawców, większej ochrony rynków krajowych, nasilanie się akcji rządów przeciwko przenoszeniu

39 W 2014 r. firma Apple ( $\mathrm{z}$ branży komputerowo-internetowej) uzyskała przychody o wartości 87 mld USD, podczas gdy roczny PKB Omanu wynosil $82 \mathrm{mld}$ USD. Ze sklepu internetowego Amazon korzysta $244 \mathrm{mln}$ użytkowników rocznie, a ludność Brazylii liczy $204 \mathrm{mln}$ osób. Vodafone, będący największym na świecie dostawcą usług telekomunikacyjnych, obsługuje $461 \mathrm{mln}$ klientów, a populacja USA wynosi 323 mln osób. Inne przykłady w publikacji: P. Khanna, Rise of the Titans, „Foreign Policy” March/April 2016, s. $51-53$. 
produkcji za granicę, podjęcie wspólnych prac przez wiele krajów nad ukróceniem niepłacenia podatków przez $\mathrm{KTN}^{40}$. Z drugiej strony, wyrażane są opinie, że „tradycyjne" KTN mają zdolność do odnawiania biznesu (twórczej destrukcji), a obecnie są w trudnej fazie zmian technologicznych i dostosowań do regulacji rynków przez politykę państwa. W przypadku amerykańskich korporacji już następuje częściowy „odwról” niektórych KTN (np. w przemyśle samochodowym, komputerowym) od globalnego biznesu i większe zaangażowanie na rynku krajowym. Zmiany lokalizacyjne wymagają dostosowań w strukturach organizacji, różnych strategiach i działalności operacyjnej korporacji. Sytuacja firm oferujących nowoczesne usługi jest lepsza niż producentów wyrobów przemysłowych, ale niepewna z powodu zamierzeń zwalczania oligopoli przez niektóre państwa, szybkich zmian technologicznych oraz słabych, międzynarodowych regulacji w zakresie handlu nowoczesnymi usługami, jak też niepełnej ochrony własności intelektualnej. Znaczenie i zmiany w działalności badawczo-innowacyjnej KTN w wymiarze globalnym zostaną przedstawione w punkcie 2.1, dotyczącym czynników technologicznych w procesie globalizacji.

Oddziaływanie państw narodowych na przebieg procesu globalizacji i ekspansji KTN jest znaczące, zarówno przez wprowadzanie prorynkowych zmian w gospodarce krajowej, jak i przez kształtowanie - za pośrednictwem organizacji międzynarodowych - warunków do swobodnej wymiany w gospodarce światowej. Neoliberalny kurs w polityce ekonomicznej uruchomił mechanizm erozji państwa w wielu krajach, a w rezultacie nastąpiło znaczne osłabienie jego pozycji w gospodarce i społeczeństwie ${ }^{41}$. Krytyce osłabionego państwa narodowego w wielu krajach towarzyszą pochlebne opinie na temat wiodącej roli państwa w transformacji i modernizacji gospodarki w Chinach. Podejście państwa do roli w gospodarce zmieniło się w okresie 2008+ i następuje odbudowa jego pozycji ekonomicznej. Należy wskazać na nowe lub wzmocnione działania państwa w następujących dziedzinach ${ }^{42}$ :

- Krytyka globalizacji z powodu rozprzestrzenienia się na świecie kryzysu finansowego (powstałego w USA) i skutków globalnej konkurencji, ujawniających się na rynkach krajowych (penetracja rynku przez obce towary i KTN, „podcinanie” krajowych firm i przemysłów, wzrost bezrobocia, obniżki płac, „wyciek” nowych technologii itd.).

\footnotetext{
40 Multinationals..., op.cit., s. 1-12.

41 J. Kleer, Specyfika panistwa wspótczesnego. Państwo wspótczesne i mechanizmy jego destrukcji, [w:] Dokąd zmierza Europa, op.cit., s.18-38. W cytowanej publikacji na temat ekonomicznej roli współczesnego państwa piszą równiė̇ K. Żukrowska, P. Kozlowski, K. Prandecki, J. Osiatyński, A. Zorska.

42 Jak w poprzednim odnośniku oraz Polityka publiczna we wspótczesnym państwie, red. J. Osiński, Oficyna Wydawnicza SGH, Warszawa 2014; M. Mazzucato, The Entrepreneurial State. Debunking Public vs. Private Sector Myths, Anthem Press, London 2014; Quo Vadis. World Economy and Institutions at a Crossroads, red. M. Baldassarri, Palgrave Macmillan, Houndmills-Basinstoke 2015.
} 
- Wzmocnienie ochrony rynku krajowego (przy słabym wzroście gospodarczym) przed napływem zagranicznych towarów przez wdrażanie tzw. ciemnej protekcji, czyli instrumentów niepodlegających porozumieniom WTO.

- Zwiększenie poparcia dla nieformalnej współpracy międzynarodowej w ramach G-20, zmniejszenie presji na przebudowę organizacji o zasięgu globalnym, osłabienie poparcia dla porozumień wielostronnych (CETA, TTIP) wspierających konkurencję na rynku globalnym i swobodę działalności KTN.

- Podjęcie ostrej krytyki, wprowadzanie restrykcji czy niekorzystnych stawek podatkowych w celu ograniczenia delokalizacji produkcji (również miejsc pracy, nowych technologii, kapitału) za granicę przez KTN.

- Podjęcie prac na poziomie ponadnarodowym w celu ograniczenia niekorzystnych praktyk biznesowych KTN (m.in. eksport kapitału do tzw. rajów podatkowych, ceny transferowe, unikanie opodatkowania na wiele sposobów).

- Wzmocnienie zaangażowania przedsiębiorstw w podnoszenie innowacyjności krajowej dzięki nowego typu polityce innowacyjnej, z udziałem „przedsiębiorczego” państwa silniej angażującego się w tworzenie i stosowanie nowych technologii.

- Opracowanie koncepcji reindustrializacji (w oparciu o nowe technologie) gospodarek krajów rozwiniętych, w tym Unii Europejskiej.

- Zwalczanie konfliktów politycznych i terroryzmu o charakterze międzynarodowym, pomoc dla uchodźców, wspieranie akcji humanitarnych.

Następuje ewolucja podejścia i polityki państwa do problemów ekonomicznych, które częściowo powstały wskutek działalności KTN na drugim etapie globalizacji. Z drugiej strony, zmienia się sposób działania korporacji w krajach goszczących, który obecnie cechuje się selektywnością w wyborze rynków, większym dostosowaniem do lokalnych warunków, zwiększaniem korzyści dla goszczącej gospodarki, lepszym komunikowaniem się ze społeczeństwem danego kraju ${ }^{43}$. W tym kontekście warto wskazać na zmiany relacji zachodzące w układzie korporacje transnarodowe-państwa narodowe (KTN-PN).

Do oceny zmian relacji w układzie KTN-PN można wykorzystać metodę opracowaną przez A. Rugmana, A. Verbeke’a i N. Greidanusa ${ }^{44}$. Analiza jest prowadzona na trzech poziomach tendencji odnoszących się do działalności korporacji i państw narodowych: makroekonomicznym, instytucjonalnym, strategicznym. Ocena makroekonomiczna dotyczy zgodności celów działalności korporacji i państw narodowych. Z przedstawionych rozważań wynika, że stopień zgodności celów tych podmiotów

43 P. Ghemawat, op.cit., s. 122.

44 A. Rugman, A. Verbeke, N. Greidanus, Multinational Enterprises and Governments: An Analysis of New Trends, [w:] The Accountable Corporation. Business Government Relations, red. M.J. Epstein, K.O. Hanson, Praeger, Westport, Connecticut-London 2006, s. 145-169. 
obniża się: państwa stają się bardziej zorientowane na rynki krajowe i wspieranie lokalnych przedsiębiorstw, a dla KTN ważny jest rynek globalny. Ocena instytucjonalna dotyczy sytuacji gospodarczej krajów i rozproszenia aktywów (ZIB) posiadanych przez KTN. W okresie 2008+ sytuacja ekonomiczna na świecie była i jest niekorzyst na, a strumienie ZIB lokowanych przez korporacje nie rosną i nie rozszerza się ich zakres geograficzny (częściowo nie dotyczy to chińskich KTN). Na poziomie strategicznym działalności korporacji może nasilać się tendencja do ograniczania ekspansji zagranicznej i częściowego odwrotu od globalnych strategii KTN (z tradycyjnych przemysłów), co będzie skutkować powrotem do strategii o niższym poziomie integracji ponadgranicznej. Globalnie działające korporacje $z$ nowoczesnych branż usługowych są w lepszej sytuacji, ale możliwości dalszej, szybkiej penetracji rynku globalnego nie są pewne. Skłania to do wniosku, że gotowość do współpracy i rozwijania przyjaznych relacji w układzie KTN-PN zostanie zahamowana, a większych dostosowań i ograniczeń należy oczekiwać ze strony korporacji. Relacje korporacji transnarodowych i państw narodowych mogą w obronie interesów niekiedy nabierać charakteru konfrontacyjnego, co nie będzie sprzyjać postępowi globalizacji.

\section{Zmiany w obecnym działaniu czynników globalizacji}

Czynniki kształtujące proces globalizacji zostały ujęte na killka sposobów różniących się (lecz nie wykluczających), w trzech lub czterech grupach ${ }^{45}$. Szerokie podejście do ważnych i złożonych zmian dokonujących się obecnie w światowej ekonomii uzasadnia wybór czterech grup czynników - czyli sił, w ujęciu autorów cenionego podręcznika - którymi są: czynniki technologiczne, ekonomiczne, społeczne oraz polityczne i prawne ${ }^{46}$. Na potrzeby rozważań w niniejszej pracy przyjmuje się zmodyfikowane ujęcie omawianych czynników, a przedstawia je rysunek 1.

45 Przykładowo, J. Rymarczyk wymienia cztery grupy czynników globalizacji, którymi są: czynniki techniczne i technologiczne, polityczne, ekonomiczne i socjopsychologiczne. Zdaniem A. Zorskiej można wyodrębnić trzy grupy omawianych czynników: postęp naukowo-techniczny, konkurencja międzynarodowa i polityka ekonomiczna państwa. W ujęciu G.S. Yipa na poziomie sektora globalizację warunkują cztery grupy czynników, którymi są: czynniki rynkowe, kosztowe, konkurencyjne i rządowe. Źródła: J. Rymarczyk, Biznes międzynarodowy, PWE, Warszawa 2012, s. 31, rys. 1.1; A. Zorska, Ku globalizacji? Przemiany w korporacjach transnarodowych $i$ w gospodarce światowej, Wydawnictwo Naukowe PWN, Warszawa 2000, s. 21-22; G.S. Yip, Strategia globalna, PWE, Warszawa 2004, s. 43, rys. 4. Ujęcie autorów G. Stonehouse et al. zostanie omówione dalej.

${ }_{46}$ G. Stonehouse, J. IJamill, D. Campbell, T. Purdie, Globalizacja. Strategia i zarządzanie, Felberg SJWiley, Warszawa 2001, s. 24-27, rys. 2.1. 
Rysunek 1. Grupy czynników ksztaltujących proces globalizacji gospodarki

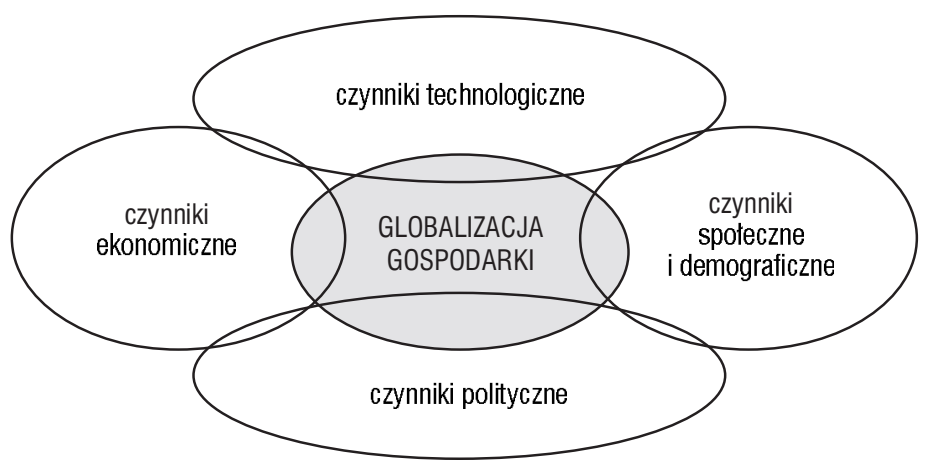

Źródło: Opracowanie własne z uwzględnieniem rysunku z publikacji G. Stonehouse, J. Hamill, D. Campbell, T. Purdie, Globalizacja. Strategia i zarzadzanie, Felberg SJ-Wiley, Warszawa 2001, s. 25, rys. 2.1.

Wskutek ograniczonej objętości artykułu nie jest możliwe omówienie wszystkich czynników w równie szczegółowy sposób, toteż naświetlone zostaną tylko najważniejsze ich elementy, ze wskazaniem szerszego ujęcia w literaturze tematu. Problem wyboru polega też na hierarchizacji grup czynników, gdyż okresowo zmienia się ich znaczenie i oddziaływanie. Omawiane grupy czynników cechuje przenikanie się oraz interakcyjność, a nawet częściowo współzależność. Na rysunku 1 wyraża to „zachodzenie" elips przypisanych do poszczególnych grup czynników. Istotne jest wskazanie kierunku wpływu czterech grup i wybranych czynników na przebicg oraz charakterystykę globalizacji, jak też na kierunki dostosowań podmiotów w różnych sferach ekonomicznych w przyszłości.

\subsection{Czynniki technologiczne}

Grupa czynników związanych z postępem naukowo-technicznym została wysunięta w dotychczasowych badaniach procesu globalizacji na czołową pozycję. Wynika to $z$ bardzo szerokiego wpływu postępu technicznego na zmiany w funkcjonowaniu i działaniach różnych podmiotów gospodarczych w ich działalności krajowej i międzynarodowej. Produkcji nowoczesnych wyrobów i usług towarzyszy ich eksport i lokowanie ZIB dla obsługi obcych rynków, rozwój transferu technologii i kooperacja technologiczna w skali międzynarodowej, stosowanie ponadgranicznych struktur i strategii przez korporacje, prowadzenie prac $\mathrm{B}+\mathrm{R}$ w zagranicznych ośrodkach, przepływy specjalistycznych kadr badawczych ${ }^{47}$. Umoziliwia to globalne tworzenie

47 Cornell University, INSEAD, WIPO, The Global Innovation Index 2016. Winning with Global Innovation, Ithaca-Geneva 2016, s. 76-78. 
i rozprzestrzenianie się wiedzy, nowych technologii, innowacji technologicznych (i innych) przez handel, inwestycje, sieci informacyjne oraz współpracę podmiotów z różnych krajów. W globalizowaniu technologii wiodącą rolę odgrywają KTN, jako podmioty wykonujące największą część prac $\mathrm{B}+\mathrm{R}$ (i nakładów na ten cel) na świecie, dominujące w międzynarodowym transferze technologii, jak tė̇ wykorzystujące nowe technologie w biznesie i rywalizacji na rynku globalnym ${ }^{48}$. Rewolucja informacyjna zintensyfikowała globalizowanie technologii przez wszystkie podmioty oraz zwiększyła znaczenie postępu naukowo-technicznego, jako siły napędzającej postęp i zmiany w procesie globalizacji ekonomicznej ${ }^{49}$.

Wpływ informacyjnych i komunikacyjnych technologii (IKT) - bazujących na internecie - na przemiany mikroekonomiczne nabrał duzego znaczenia po roku 2001, czyli po kryzysie spólek internetowych. Do czasu kryzysu 2008-2009 miał miejsce dynamiczny wzrost podaży nowych technologii informacyjnych, ich szerokie zastosowanie i rozprzestrzenianie się $w$ gospodarce i społeczeństwie. Kryzys finansowy spowodował obniżenie nakładów B+R na świecie w 2010 r., zahamowanie modernizacji przedsiębiorstw i ukierunkowanie wdrażania technologii na oszczędności kosztowe. W ostatnim dziesięcioleciu kompleksowy wpływ rewolucji technologicznej na unowocześnienie i umiędzynarodowienie biznesu dokonuje się na różnych płaszczyznach i wyraża się następującymi zmianami:

- Szybką modernizacją biznesu przedsiębiorstw z tzw. tradycyjnych gałęzi przemysłu przetwórczego i usług, $\mathrm{z}$ wykorzystaniem własnych prac B+R i/lub szybko rosnącej podaży nowych technologii produkcyjnych oraz infrastrukturalnych z zewnątrz.

- Dynamiczną ekspansją spółek z branż sektora informacyjnego, które wytwarzają i oferują innowacyjne produkty usługowe i szybko penetrują rynek globalny.

- Przekształcaniem lub rozwijaniem struktur organizacji o charakterze sieciowym we wszystkich przedsiębiorstwach i branżach, adaptowaniem różnych strategii do nowych warunków konkurencji na rynku globalnym.

- Przenoszeniem fragmentów procesu wytwarzania wyrobów i usług poza kraj macierzysty w celu wykorzystania walorów lokalizacji zagranicznych do podniesienia efektywności biznesu oraz globalnej konkurencyjności produktów i firm.

- Umiędzynarodowieniem działalności B+R przez lokowanie badań lub ich fragmentów w różnych krajach, jak też przez rosnące przepływy wiedzy i technologii na świecie.

\footnotetext{
48 A. Zorska, Korporacje transnarodowe. Przemiany, oddzialywania, wyzwania, PWE, Warszawa 2007, s. $107-117$.

49 Szerzej na ten temat: M.A. Weresa, Globalizacja działalności innowacyjnej we wspótczesnej gospodarce światowej, „Zeszyty Naukowe Kolegium Gospodarki Światowej SGH” czerwiec 2008, s. 9-27.
} 
W przenoszeniu produkcji za granicę kumulują się różne innowacyjne rozwiązania technologiczne we wszystkich działaniach tworzących wartość dodaną firm, w organizacji, zarządzaniu i strategiach konkurencji, infrastrukturze komunikacyjnej, sposobach ekspansji zagranicznej, relacjach $z$ innymi podmiotami, w wymaganiach wobec zagranicznych lokalizacji. Zdaniem R. Baldwina przenoszenie produkcji (offshoring) wyrobów i usług $z$ krajów wysoko rozwiniętych do krajów mniej rozwiniętych (o niskich kosztach wytwarzania i odpowiednich zdolnościach technologicznych) stało się procesem techniczno-ekonomicznym o zasadniczym znaczeniu dla postępu globalizacji w ostatnim dwudziestoleciu, zwłaszcza po kryzysie spółek internetowych (w 2001 r. $)^{50}$. Nowe technologie informacyjne i komunikacyjne - wraz ze zmianami w strukturach organizacji firm - zwiększyły rozczłonkowanie (rozbicie, fragmentację) łańcuchów tworzenia wartości dodanej oraz przenoszenie wybranych działań (np. produkcyjnych) do krajów o lepszych warunkach dla ich realizacji. Co istotne, $z$ przenoszeniem fragmentów produkcji (oraz innych działań) był związany transfer wiedzy, technologii oraz know how (a często tė̇ kapitału) do krajów mniej rozwiniętych.

Dzięki przenoszeniu produkcji za granicę korporacje z krajów rozwiniętych podnoszą efektywność i konkurencyjność biznesu, podczas gdy w ich macierzystych gospodarkach kumulują się koszty offshoringu, zarówno realne, jak i potencjalne (korzyści uważane są za dużo mniejsze). Następuje spadek zatrudnienia, produkcji, wpływów podatkowych, odpływ wiedzy, technologii, kapitału, specjalistów, zahamowanie dynamiki eksportu i globalnej konkurencyjności itd. Zachodnie firmy poszukują w innych krajach nie tylko niższych kosztów wytwarzania, lecz coraz częściej również innych, korzystnych walorów lokalizacji zagranicznych, zwłaszcza nowej wiedzy lub dobrych warunków do jej tworzenia. W grupie sześciu krajów najbardziej znaczących dla lokowania offshoringu i najszybciej rozwijających zdolności technologiczne, zdaniem R. Baldwina, znajdują się: Chiny, Korea Południowa, Indie, Indonezja, Tajlandia i Polska ${ }^{51}$. Powiązany $z$ offshoringiem napływ kapitału, nowych technologii oraz dostęp do metod biznesowych i sieci KTN stworzyły silne impulsy dla rozwoju w tych krajach zasobów i zdolności technologicznych, produkcji wyrobów i usług, eksportu, biznesu lokalnego, dochodów i konsumpcji. Dzięki transferowi wiedzy i technologii z zagranicy te i inne kraje realizujące przeniesioną produkcję stały się beneficjentami globalizacji. Co istotne, obecnie w wielu państwach - zwłaszcza azjatyckich - dokonuje się intensyfikacja krajowej działalności

50 R. Baldwin, The Great Convergence. Information Technology and the New Globalization, The Belknap Press of Harvard University Press, Cambridge, Mass.-London 2016, s. 5-10.

51 Ibidem, s. 86 
badawczo-innowacyjnej, powstają nowe dziedziny produkcji i eksportu, rozwijają się krajowe firmy, stając się rywalami zachodnich korporacji. Wiedza, technologie, innowacje nadal w dużym stopniu decydują o międzynarodowej konkurencyjności firm i gospodarek, jak też o ich uczestnictwie i korzyściach z globalizacji.

Przyszłe zasoby nowej wiedzy i technologii dostępne dla przedsiębiorstw powstaną dzięki obecnym nakładom na prace badawczo-rozwojowe (B+R), toteż zmiany w tym zakresie mają istotne znaczenie dla gospodarki światowej i globalizacji. Globalna wartość wydatków na prace badawczo-rozwojowe $\left(G_{E R D}{ }^{52}\right)$ ze źródeł publicznych i prywatnych zwiększyła się z 1.132 mld USD w 2007 r. do 1.447 mld USD w 2013 r., co oznacza wzrost o 30,5\%. W latach 2007-2013 przeciętna relacja wartości nakładów na badania do PKB na świecie podniosła się z 1,57\% do 1,70\% ${ }^{53}$. Wzrost wydatków na prace $\mathrm{B}+\mathrm{R}$ był zróżnicowany w poszczególnych krajach i grupach krajów, co skutkuje zmianą światowej struktury tych wydatków. W latach 2007-2013 udział krajów rozwiniętych (o wysokich dochodach) obniżył się z 79,7\% do 69,3\% (tzn. o 10,6 pkt. proc.), podczas gdy udział krajów mniej rozwiniętych wzrósł do 20,3\%. Wśród „potęg badawczych” na świecie przodują Stany Zjednoczone. W 2013 r. wartość nakładów $\mathrm{B}+\mathrm{R}$ poczynionych w USA osiągnęła $386,7 \mathrm{mld}$ USD, ale ich udział obniżył się z 31,7\% do $28,1 \%$ (o 3,6 pkt. proc.) globalnego GERD. Na drugim miejscu na świecie uplasowały się Chiny, wydatkując 290,1 mld USD, przy czym udział tego kraju w globalnych nakładach B+R zwiększył się z 10,2\% do 19,6\% (o 9,4 pkt. proc.) w okresie 2007-2013. Narasta globalna rywalizacja technologiczna między USA i Chinami, przy czym chiński sektor $B+R$ otrzymuje silniejsze wsparcie ze strony państwa. Co istotne, Chiny wyprzedziły kraje Unii Europejskiej, gdzie wszystkie kraje łącznie wydatkowały w 2013 r. 282,0 mld USD. Należy dodać, że łączny udział UE w globalnych nakładach badawczych obniżył się o 3,1 pkt. proc., do 19,1\%54. Badacze UNESCO zauważają, że w okresie 2008+ miało miejsce ograniczanie inwestycji w badania i rozwój przez sektor publiczny w krajach rozwiniętych, podczas gdy zwiększają się tego rodzaju nakłady w krajach mniej rozwiniętych (ale nakłady te nadal pozostają na niskim poziomie). Barierami rozwoju sektora $B+R$ w grupie uboższych krajów pozostaje brak kadr badawczych oraz niedostateczna infrastruktura.

Nakłady na działalność $\mathrm{B}+\mathrm{R}$ ponoszone na świecie przez 1000 największych przedsiębiorstw (KTN) zwiększają się od 2011 r., ale występują wahania poziomu nakładów, a w $2016 \mathrm{r}$. ich wartość powiększyła się tylko o 0,04\%. Stany Zjednoczone przyjmują najwięcej inwestycji płynących z zagranicy do sektora B+R (53 mld USD

52 GERD jest skrótem terminu gross expenditure on research and development.

53 UNESCO, UNESCO Science Report. Towards 2030. Executive Summary, UNESCO Publ., Paris 2016, s. 6-9, w tym tab. 1.2. Uwaga: wartość GERD podana jest $z$ uwzględnieniem parytetu sily nabywczej walut.

54 Ibidem, obliczenia własne. 
w 2015 r.), ale szybko rośnie napływ środków zachodnich KTN do działalności badawczej w Chinach (stopa wzrostu 27\% w 2015 r., wartość 44 mld USD). W przekroju gałęziowym korporacyjne nakłady $B+R$ na świecie są lokowane przede wszystkim w przemyśle komputerowym i elektronicznym $24 \%$, w urządzeniach ochrony zdrowia $21 \%$, w przemyśle samochodowym $16 \%$ oraz w branży oprogramowania i internetu $11 \%$ (najwyższy wzrost o 27,4\% w $2015 \mathrm{r}$. ${ }^{55}$. Zatem na hardware i software w sektorze informacyjnym przypada ponad $51 \%$ nakładów na prace $B+R$ przez największe przedsiębiorstwa na świecie, co świadczy o ukierunkowaniu postępu technologicznego na wiedzę, technologie, innowacje generowane przez ten sektor. Ponieważ technologie informacyjne stanowią ważny komponent modernizacyjny (automatyka, robotyka) dla wszystkich branż gospodarki, to w przyszłości wdrożenie wyników tych badań (jako innowacji w różnych dziedzinach) może przynieść dużą „falę" zmian technologicznych w przedsiębiorstwach, sektorach i gospodarkach.

Analiza działalności badawczo-innowacyjnej KTN na świecie wykazała wysoki stopień umiędzynarodowienia tej działalności: obecnie $94 \%$ korporacji prowadzi prace $B+R$ poza krajem macierzystym ${ }^{56}$. Jako główne motywy inwestowania w sektorze $\mathrm{B}+\mathrm{R}$ za granicą korporacyjni specjaliści podają poszukiwanie utalentowanych kadr i bliskość do klientów, a nie ulgi podatkowe na badania przyznawane przez państwa goszczące. Na świecie Azja stała się głównym regionem napływu inwestycji zagranicznych do działalności badawczej, przeganiając USA i UE. Unia Europejska przesunęła się na niższą, trzecią pozycję wśród regionów przyjmujących zagraniczne środki do sektora badawczego, natomiast w 2015 r. silnie wzrósł odpływ inwestycji $\mathrm{w}$ prace $\mathrm{B}+\mathrm{R} z$ Unii (głównie $z$ Francji i Niemiec) do USA i innych krajów $w^{57}$. Zmiany w globalnych strumieniach inwestycji badawczych będą skutkować przesunięciami w światowych strukturach produkcji i wymiany w przyszłości.

Przedstawione zmiany w inwestycjach KTN w działalność badawczą na świecie sygnalizują stosunkowo nową tendencję do przenoszenia korporacyjnych prac B+R za granicę, która ma coraz większe znaczenie dla oddziaływania czynników technologicznych na przebieg procesu globalizacji. Korzyści z offshoringu produkcji przemysłowej zachęciły KTN do przenoszenia części działalności badawczej (projektów, zadań) do ulokowanych za granicą własnych ośrodków B+R i/lub filii produkcyjnych posiadających duże działy badawczo-wdrożeniowe. Centralne laboratoria KTN w krajach macierzystych nadal prowadzą badania o znaczeniu strategicznym, ale

55 B. Jaruzelski, V. Staack, K. Schwart, The 2015 Global Innovation 1000: Innovation's New World Order, Strategy \& PCW, October 2015, http://www.strategyand.pwc.com/global/home/press/displays/innovations-new-world-order [dostęp 23.07.2016].

56 Ibidem.

57 Ibidem. 
fragmenty prac powierzają innym jednostkom i partnerom. Korporacje inwestują w ośrodki badawcze w wielu krajach (o korzystnych walorach lokalizacji), rozdzielają zadania i projekty między różne ośrodki, co prowadzi do geograficznego rozproszenia i umiędzynarodowienia prac $B+R$, a jednocześnie wymaga ich ponadgranicznej koordynacji oraz integracji. Co istotne, w krajach goszczących korporacyjne jednostki badawcze rozwija się współpraca technologiczna $z$ krajowymi podmiotami, którymi zwykle są lokalne ośrodki B+R, uczelnie oraz innowacyjne firmy ${ }^{58}$. Nowa wiedza jest tworzona wspólnie (często w ramach NSI), ale często zostaje przejęta przez korporacyjne jednostki i transferowana do macierzystej firmy. Korzyści KTN polegają na zmniejszeniu kosztów, ryzyka i czasu trwania badań, przy podniesieniu jakości ich wyników, tzn. potencjału komercyjnego na rynku globalnym. Wzrastają międzynarodowe przepływy wiedzy, nowych technologii, specjalistów w ramach korporacyjnych sieci badawczych, $z$ udziałem zagranicznych partnerów badań. W rezultacie KTN posiadają zasób wiedzy i technologii pochodzący z różnych źródel, który wykorzystują do umacniania sowich przewag konkurencyjnych na rynku globalnym. W konsekwencji offshoringu badawczego zmienia się wpływ ekspansji KTN na proces globalizacji, gdyż aktywizują się przepływy niematerialne (wiedza, nowe technologie), pogłębia się międzynarodowy podział pracy, a korporacje zajmują w nim strategicznie ważne pozycje, tworzone są podstawy nowych struktur produkcji i wymiany gospodarczej na świecie w przyszłości.

$\mathrm{W}$ dobie rewolucji informacyjnej działanie postępu naukowo-technicznego, za pośrednictwem wdrażających go podmiotów, można uważać za ogólnie stymulujące wzrost w gospodarce światowej i postęp globalizacji. Zdaniem specjalistów technologie informacyjne wywierają obecnie większy wpływ na globalną gospodarkę dzięki uruchomieniu przepływów wyrobów, usług i kapitału - a także udostępnianiu idei, danych, informacji, rozrywki - niż tradycyjne strumienie handlu międzynarodowego $^{59}$. Jednak obecny potencjał wiedzy i nowych technologii może nie być w pełni wykorzystany w sferze ekonomicznej, gdyz istnieją przeszkody w globalizowaniu biznesu. Od strony techniczno-organizacyjnej przeszkody w rozwijaniu innowacyjności na świecie przez KTN wynikają z następujących problemów: trudności w zarządzaniu globalnym biznesem wielkich KTN, dysproporcje w technicznym poziomie infrastruktury informacyjno-komunikacyjnej w różnych krajach, rớżnice w standardach i regulacjach technicznych na świecie, problemy w transporcie specjalnych

58 Szerzej na ten temat patrz: A. Zorska, Umiędzynarodowienie prac $B+R$ w korporacjach transnarodowych oraz wplyw tego procesu na innowacyjność w krajach goszczacych, [w:] Innowacyjność i konkurencyjnośc międzynarodowa. Nowe wyzwania dla przedsiębiorstw i polityki państwa, red. A. Janowska, R. Malik, R. Wosiek, Oficyna Wydawnicza SGII, Warszawa 2017, s. 153-180.

59 Opinia badaczy McKinsey Global Institute, cytowana przez S. Mallaby, op.cit., s. 10. 
towarów, niektóre instrumenty polityki państwa (np. zbyt małe ulgi podatkowe) itd. ${ }^{60}$ Jednak bardziej znaczących destymulatorów procesu globalizacji obecnie nie należy poszukiwać w dziedzinie postępu technologicznego, lecz w innych grupach czynników globalizacji.

\subsection{Czynniki ekonomiczne}

Grupa czynników ekonomicznych obejmuje szereg procesów, zjawisk i struktur w gospodarkach poszczególnych krajów i świata, które mają wpływ na przebieg globalizowania działalności ekonomicznej na różnych poziomach (mikro, mezo, makro). J. Rymarczyk zalicza do ekonomicznych czynników globalizacji: kosztowe zróżnicowanie krajów, rozwój infrastruktury materialnej w krajach rozwijających się, innowacyjność w produkcji (w tym korzyści skali wytwarzania), zarządzaniu i organizacji przedsiębiorst $w^{61}$. Zatem chodzi o korzyści firm $z$ prowadzenia biznesu w sposób innowacyjny i rozproszony międzynarodowo, wykorzystujący walory lokalizacji w różnych krajach. Jako siły ekonomiczne stymulujące globalizację G. Stonehouse et al. wymieniają rozwój handlu i finansów w skali światowej, konkurencję na rynku globalnym, wzrastające dochody indywidualne w wielu krajach ${ }^{62}$. W takim ujęciu zmian czynników ekonomicznych należy poszukiwać w rozwoju i funkcjonowaniu rynku globalnego, uwzględniając rosnący popyt na różnych rynkach krajowych. Wspólną płaszczyzną obu ujęć jest rynck globalny (podaż, popyt, warunki konkurencji) oraz działające na nim podmioty biznesowe, zwłaszcza KTN. Jednak zachodzące w ostatnich latach przemiany w gospodarce światowej uzasadniają szerszą perspektywę z zakresu ekonomii międzynarodowej, polegającą na uwzględnieniu zmian ekonomicznych w grupach podmiotów wyższej rangi, tzn. krajów (oraz ich gospodarek) uczestniczących w globalizacji. Wśród czynników globalizacji analizowanych od strony ekonomii międzynarodowej należy wskazać: przemiany strukturalne i zróżnicowanie dynamiki wzrostu gospodarczego w różnych krajach, postęp technologiczny, znaczenie eksportu towarów i kapitałów (w relacji do PKB), zmiany konkurencji na rynku globalnym, stan zadłużenia, zaangażowanie państwa w organizacjach i akcjach międzynarodowych, przepływy ludności, rozwój turystyki itp. ${ }^{63}$

60 J. Rymarczyk, op.cit., s. 41-42.

61 Ibidem, s. 38-39.

62 G. Stonehouse et al., op.cit., s. 25-27.

63 Jest to ujęcie częściowo zbliżone do opracowanej przez agencję AT Kearney oraz redakcję „Foreign Policy" koncepcji badania uczestnictwa krajów w globalizacji, co skutkowało sporządzeniem rankingu państw zaangażowanych w tym procesie. Badania i ranking zostały wstrzymane jeszcze przed kryzysem $2008 \mathrm{r}$. Więcej na temat wyników badań w ostatniej publikacji: „Foreign Policy” November/December 2007, s. $67-76$. 
Część tych zagadnień została naświetlona w punkcie 1 artykułu, a ponadto można polecić ich szersze omówienie $w$ dostępnej literaturze ${ }^{64}$. Poniżej skoncentrujemy się na tych procesach i zmianach struktury gospodarek krajów rozwiniętych, rozwijających się, gdzie nastąpily najbardziej znaczące przekształcenia od czasu kryzysu, mogące oddziaływać na dalszy przebieg globalizacji.

Zasadniczą kwestię ekonomiczną stanowią zmiany dynamiki i struktury gospodarki światowej. W latach 2008-2014 tempo wzrostu światowego PKB wynosiło przeciętnie 2,2\% rocznie, podczas gdy przed wybuchem kryzysu - w latach 2004-2007 - ukształtowało się na poziomie przeciętnie 3,9\% ${ }^{65}$. Osłabienie po kryzysie $2008+$ wyrażało się niskim tempem wzrostu ekonomicznego krajów rozwiniętych wynoszącym średniorocznie $0,9 \%$, podczas gdy w tym czasie duża grupa krajów rozwijających się osiągnęla dynamikę na poziomie $5,4 \%$, a kraje transformujące się utrzymały tempo $2,3 \%{ }^{66}$. Należy zwrócić uwagę, że wśród krajów rozwiniętych kryzys gospodarczy i późniejszy osłabiony wzrost przebiegały w sposób zróżnicowany, przy czym w Europie tempo wzrostu wynosiło średnio 0,2\%, w Japonii 0,7\%, a w USA 1,4\% w latach 2008-2014 ${ }^{67}$. Stosunkowo wysokie tempo wzrostu gospodarczego utrzymało się w krajach Europy Środkowej, zwłaszcza w Polsce (średnio 3,1\% rocznie). Kraje środkowoeuropejskie podnoszą poziom rozwoju i umiędzynarodowienia gospodarek.

Wzrost gospodarczy krajów rozwijających się również cechował się zróżnicowaniem dynamiki w okresie 2008-2014, a relatywnie wysoką stopę wzrostu utrzymały Chiny - przeciętnie $8,9 \%$ oraz Indie 7,0\% ${ }^{68}$. W pozostałych krajach grupy BRIC nastąpiło obniżenie dynamiki do $2,9 \% \mathrm{w}$ przypadku Brazylii oraz do 1,9\% w Rosji ${ }^{69}$. Co istotne, w omawianym okresie przeciętny poziom na mieszkańca wzrastał średnio zaledwie o 0,4\% rocznie w krajach rozwiniętych, podczas gdy dla PKB per capita w Chinach analogiczny wskaźnik dynamiki przeciętnego PKB wynosił 8,2\%, a w Indiach 5,7\% (przy szybszym wzroście indyjskicj populacji). Należy dodać, że kraje rozwinięte

64 A. Zielińska-Glębocka, op.cit.; Dokad zmierza Europa, op.cit.; M. Baldassarri, Quo Vadis: World Economy and Institutions at Crossroads, Palgrave-MacMillan, New York 2015; Państwa grupy BRICS $i$ ich znaczenie w gospodarce światowej, red. T. Sporek, K. Czech, Wydawnictwo UE w Katowicach, Katowice 2015.

65 Źródło: UNCTAD, UNCTAD Handbook of Statistics 2016, op.cit., s. 348-354, tab. 8.2. Uwaga: dane dla roku 2014 sa szacunkowe.

66 Chodzi transformujące się kraje w Europie, głównie WNP - w tym Rosję, byłe kraje Jugosławii oraz inne.

67 Ibidem, s. 348-354, tab. 8.2. (dane dla roku 2014 są szacunkowe).

68 Należy podkreślić, że grupa krajów rozwijajacych się jest wysoce heterogeniczna i obejmuje ponad 100 krajów o różniej wielkości, poziomie rozwoju i strukturze gospodarki, systemie ekonomicznym, powiązaniach zagranicznych, stanie zadłużenia itd., przy czym największe znaczenie gospodarcze mają kraje BRIC (w kolejności potencjału ekonomicznego: Chiny, Indie, Rosja, Brazylia).

69 Ibidem. Różnice te wynikają m.in. z wyposażenia poszczególnych krajów BRIC w zasoby i zdolności wytwórcze, $z$ warunków instytucjonalnych, szerokości otwarcia gospodarek i powiązań produkcyjno-handlowych z zagranicą. 
zamieszkuje niewiele ponad 1 mld ludzi, a kraje rozwijające się prawie 6 mld ludzi (przy czym ta druga liczba stosunkowo szybko powiększa się). Wzrost popytu konsumpcyjnego i inwestycyjnego może nastąpić w krajach rozwijających się o wyższym tempie powiększania się PKB (ogólnie i per capita) oraz zaludnienia, dając większe możliwości ekspansji firmom krajowym na tych rynkach, a także firmom zagranicznym - jeśli będzie utrzymany dostęp do tych rynków.

Uruchomiony został długofalowy proces konwergencji dochodów w skali globalnej, który w dużym stopniu jest następstwem przyspieszenia przepływów towarów i czynników wytwórczych między krajami rozwiniętymi i rozwijającymi się, w powiązaniu z procesem globalizacji ${ }^{0}$. Chociaż wzrost produkcji, produktywności i dochodów był zróżnicowany w poszczególnych krajach, to efekt postępu w wy równywaniu dochodów i podnoszeniu poziomu życia ludzi na świecie wystąpił. Utrzymujący się wzrost dochodów w krajach mniej rozwiniętych może silniej ukierunkować biznes międzynarodowy ku tym krajom, zwiększając wpływ takiej reorientacji strumieni handlu i ZIB na przebieg procesu globalizacji.

Znaczące zmiany dokonują się w strukturach sektorowej i gałęziowej produkcji oraz wymiany handlowej na świecie. Technologie cyfrowe zdynamizowały rozwój sektora usług dzięki innowacyjnemu wykorzystaniu tych technologii do wytwarzania i eksportu różnego rodzaju usług. Jednak kryzys 2008-2009 załamał dynamikę wzrostu sektora usługowego. Po dramatycznym spadku wartości usług finansowych w latach 2007-2009 w kolejnych latach nastąpił wzrost podaży i obrotów w sektorze finansowym, co przyczyniło się do odbudowania poziomu udziału w światowym PKB. W 2014 r. usługi osiągnęły 68,4\% wartości światowego PKB, przy czym w krajach OECD wskaźnik ten wynosił średnio 74,3\%. Największy wzrost udziału usług w PKB odnotowano w grupie krajów Azji Wschodnicj, z 55\% do 60\% w latach 2000-2015 $5^{71}$. Indie oraz Chiny znajdują się w światowej czołówce dostawców usług informacyjnych, doganiając kraje rozwinięte (Niemcy i Francja silnie odczuły spadek eksportu usług w czasie kryzysu).

Kryzys i spowolnienie gospodarcze 2008+ spowodowały wiele rynkowych zmian, które były w większości niekorzystne dla firm. Zmusiło to przedsiębiorstwa do przesuwania produkcji i zbytu ku branżom oraz rynkom mniej dotkniętym kryzysem i podwyżką kosztów, a jednocześnie do wdrażania wielu zmian podnoszących efektywność i konkurencyjnossć biznesu. Rozwój nowoczesnych usług (opartych

70 M. Obstfeld, Get on Track with Trade, „Finance and Development” December 2016, s. 13. Autor podaje, że w latach 1991-2015 nastąpił wzrost PKB na mieszkańca z 553 USD do 1806 USD w Indiach oraz z 783 USD do 6416USD w Chinach. Poziom gospodarczego rozwoju dorównujący krajom zachodnim osiągnęly: Iongkong, Singapur, Tajwan, Korea Poludniowa.

71 http://data.worldbank.org/indicator/NV.SRV.TETC.ZS [dostęp 9.05.2017]. 
na technologiach cyfrowych) stał się dobrą alternatywą lub uzupełnieniem produkcji wielu przedsiębiorstw przemysłowych. Obok zmian w strukturze produkcji przedsiębiorstw i gospodarek pogłębia się specjalizacja i wymiana wewnątrzgałęziowa oraz wymiana wewnątrzkorporacyjna. W krajach rozwiniętych (np. w USA, a także w UE) szeroko stosowanym przez korporacje sposobem dostosowań stało się przenoszenie (offshoring) fragmentów produkcji wyrobów i usług za granicę - do krajów o niższych kosztach wytwarzania, jak np. kraje Europy Środkowej, a przede wszystkim kraje azjatyckie. Lokalizacjami offshoringu często są kraje mniej rozwinięte ekonomicznie, lecz posiadające już odpowiednie zdolności technologiczne, których powstanie w latach 90 . zainicjowaly zachodnie korporacje, a dalszy rozwój wsparły krajowe rządy ${ }^{72}$. Rozwinęly się globalne lańcuchy dostaw kierowane przez KTN, które prowadzą tzw. arbitraż biznesowy, czyli wykorzystują zróżnicowane warunki zakupu, produkcji i zbytu w różnych krajach.

Z wielu krajów zwiększane są dostawy nowoczesnych wyrobów i usług na rynek globalny, co powoduje zaostrzenie konkurencji i dalsze starania przedsiębiorstw o uzyskanie przewag technologicznych i innych. Wzrastają nakłady na prace $\mathrm{B}+\mathrm{R}$ ze źródeł prywat nych i publicznych we wszystkich grupach krajów, a za globalnym przywództwem USA w tym zakresie podążają kraje Azji, głównie Chiny i Indie ${ }^{73}$. Rozwój nowoczesnej produkcji ma charakter pracooszczędny, co - wraz z przenoszeniem produkcji za granicę - niekorzystnie odbija się na rynku pracy w krajach wysoko rozwiniętych, przez obniżanie płac i powiększanie grupy ludzi bez szans na stałe zatrudnienie. Poprawę sytuacji w tym zakresie może przynieść reindustrializacja gospodarek UE i USA w oparciu o prace $\mathrm{B}+\mathrm{R}$, wiedzę, nowe technologie, innowacje zastosowane we własnym kraju. Przenoszenie nowoczesnej produkcji za granicę zostałoby w pewnym stopniu ograniczone, w pewnym stopniu hamując dynamikę wymiany międzynarodowej i częściowo postęp globalizacji.

Może to wskazywać na postępującą erozję dominacji krajów rozwiniętych w gospodarce światowej. Z jednej strony jest to rezultatem spowolnienia gospodarczego i różnych problemów krajów Triady, a z drugiej - skutkiem przyspieszenia ekonomicznego i modernizacji struktur wielu krajów mniej rozwiniętych, zwłaszcza Chin i innych państw azjatyckich. Jednakże oprócz postępu ekonomicznego na ogólnoświatowe znaczenie kraju czy grupy krajów oraz ich uczestnictwo w globalizacji

\footnotetext{
72 Szerzej na ten temat historii oraz współczesnych uwarunkowań i przebiegu offshoringu wyrobów i usług patrz: R. Malik, Lokalizacja w offshoringu ustug, CeDeWu pl, Warszawa 2016, s. 17-82.

73 W latach 2007-2015 wartość nakładów firm na działalność B+R w USA wzrosła o 35\%, podczas gdy w Chinach o 79\%, a w Indiach o 116\% (uwzględniając nakłady zagranicznych firm). Inwestycje badawczo-rozwojowe chińskich firm wzrosły z $23 \%$ do $38 \%$ poziomu inwestycji amerykańskich KTN w latach 2007-2015. Źródło: PCW, Strategy \&, October 2015, s. 8, http://www.strategyand.pwc.com/global/home/ press/displays/innovations-new-world-order [dostęp 23.07.2016].
} 
składają się też inne cechy: zdolność tworzenia wiedzy i nowych technologii, kontrola rynków finansowych, wpływ na równowagę płatniczą na świecie, dostęp do surowców naturalnych, pozycja w organizacjach międzynarodowych i polityce światowej. Czynniki ekonomiczne są różnorodne, niekiedy interakcyjne (np. w powiązaniu z czynnikami technologicznymi oraz społeczno-politycznymi) i ewoluujące, toteż tworzą złożony układ sił, mogących kształtować dalszy przebieg globalizacji w sposób trudny do przewidzenia.

\subsection{Czynniki społeczne i demograficzne}

Grupa czynników społecznych i demograficznych zwiększa oddziaływanie na przemiany ekonomiczne $\mathrm{w}$ okresie $2008+$, również na umiędzynarodowienie działalności gospodarczej. W kontekście niniejszej pracy do zasadniczych czynników tego rodzaju zaliczane są: podobieństwo gustów konsumentów, rosnący popyt (zwłaszcza na dobra konsumpcyjne), zmiany modeli zycia i konsumpcji, przesunięcia struktur klasowych w różnych krajach, nierówności dochodowe globalne i lokalne, zmiany demograficzne, migracje ludności. Współzależność zmian w działaniu takich czynników globalizacji dokonuje się głównie za pośrednictwem rynku globalnego, międzynarodowych przepływów towarów i czynników (kapitał, technologie), przepływu informacji, podróży i migracji ludzi, a także przez politykę państwa skierowaną na określone procesy i zjawiska.

Działanie czynników społeczno-demograficznych cechują różnice charakterystyczne dla krajów rozwiniętych i rozwijających się, a zasadniczym wspólnym elementem jest tendencja do upodabniania się gustów konsumentów dzięki rosnącym dochodom, zmianom modelu konsumpcji, masowej modzie i rozrywce, informacjom $z$ różnych krajów, kontaktom na portalach społecznościowych. Jednakże tendencja do homogenizacji popytu nie jest równie silna, jak w latach 90., a elementy lokalne i indywidualne są obecnie bardziej istotne. Wzrastający poziom dochodów w krajach o wyższej dynamice PKB (na mieszkańca i ogólnie) stwarza możliwości lepszego zaspokajania potrzeb, co napędza popyt na wyższej jakości nowe dobra i usługi o przeznaczeniu konsumpcyjnym. W krajach rozwijających się problemem jest wielkość grupy odbiorców, a dla produktów o wyższej wartości nierzadko są to głównie elity społeczeństwa. W skali światowej duze znaczenie ma popyt na wielkich i chłonnych rynkach zbytu w krajach azjatyckich, przede wszystkim w Chinach i Indiach. Wraz z rozwojem masowej konsumpcji jednocześnie postępuje rozwój potrzeb i zakupów przez klientów z tzw. klasy średniej w tych krajach. Ta grupa społeczna cieszy się rosnącym standardem życia, bardziej wyrafinowanym gustem i zakupami w zachodnich firmach oferujących markowe produkty, drogie gadzety itd. W krajach 
rozwijających się popyt konsumpcyjny cechuje się silnym zróżnicowaniem potrzeb różnych grup klientów, lokalną specyfiką i niepewnością sytuacji rynkowej ${ }^{74}$. Obsługa dużego popytu przez zagraniczne KTN wymaga zwiększenia ich lokalnych dostosowań oraz pokonania barier w dostępie do krajowych rynków (w tym wypadku de facto zależy od czynników politycznych).

W krajach rozwiniętych o słabym wzroście gospodarczym w okresie 2008+, odpływie miejsc pracy i dochodów za granicę, obniżaniu się płac i dochodów, zmieniających się wymaganiach pracodawców, rosnącym bezrobociu, wysokich kosztach edukacji oraz opieki zdrowotnej itd. postępuje kurczenie się klasy średniej. Niegdyś dobrze sytuowane osoby i ich rodziny odczuwają obniżanie poziomu życia, mniejsze możliwości kształcenia dzieci czy konieczność ograniczenia zakupów. Zmiany struktury społecznej stanowią element szerszego problemu rosnących nierówności dochodowych w warunkach zmian na rynku pracy w krajach rozwiniętych ${ }^{75}$. Badania wykazały pozytywną korelację między wzrostem nierówności dochodowych (w ujęciu netto) a importem tanich towarów (wypieranie $\mathrm{z}$ rynku lokalnych produktów i firm, wzrost bezrobocia), zmianami technologicznymi (cyfryzacja, automatyzacja, radykalne innowacje) oraz imigracją (rosnąca podaż taniej siły roboczej) ${ }^{76}$. Pomoc ze strony państwa dla ludzi poszkodowanych tymi zmianami jest ograniczona przez duże wydatki na pomoc dla banków i dużych firm, jak też malejące wpływy podatkowe od KTN realizujących offshoring i unikających płacenia podatków. Drugą stronę problemu nierówności dochodowych stanowi szybkie bogacenie się wąskiej grupy najzamożniejszych elit, której potrzeby konsumpcyjne w zasadzie są zaspokojone. Nie tylko są osłabione bodźce do wzrostu gospodarczego, ale $z$ drugiej strony zwiększa się poczucie niesprawiedliwości społecznej i zagrożenie dla systemu politycznego kraju ${ }^{77}$. Ponadto powiązania i bliskość najzamożniejszych elit w różnych krajach tworzą transnarodową społeczność o podobnych gustach, modelach konsumpcji, stylu życia, co może alienować tę grupę ze społeczeństwa danego kraju. Wobec słabo rosnącego popytu konsumpcyjnego na rynku krajowym zachodnie firmy będą starały się rozwijać dostawy na bardziej chłonne rynki zagraniczne. Jeśli

74 A.G. Rozhkov, M.M. Smirnowa, V.A. Rebiazina, Customer Orientation in Emerging Markets: Concepts and Empirical Tests, [w:] Emerging Markets and the Future of the BRIC Nations, red. B.L. Kedia, K. Aceto, Edward Elgar Publ., Cheltenham-Northampton 2015, s. 185.

75 J. E Stiglitz, Cena nierówności. W jaki sposób dzisiejsze podziały społeczne zagrażają naszej przyszło$s c i$ ?, Wydawnictwo Krytyki Politycznej, Warszawa 2015, s. 66-88 oraz 98. Szczególnie dużo uwagi J.E. Stiglitz poświęca procesom ekonomicznym i politycznym, które prowadzą do narastania i wysokiego poziomu nierówności dochodowych w USA, jak również analizuje takie procesy w innych krajach.

76 II. Peters, M. Volwachsen, Rising Income Inequality: Do Not Draw the Obvious Conclusions, „Intereconomics" No. 2, 2017, s. 11-118.

77 Th. Piketty, Kapital w XXI wieku, Wydawnictwo Krytyki Politycznej, Warszawa 2015, s. 312-326. Na ten temat pisze również J.E. Stiglitz, Cena nierówności..., op.cit., s. 68-69 i in. 
będą one bardziej chronione przez władze państwa, to mogą ogólnie osłabnąć przepływy towarów i kapitałów dla obsługi rynków zagranicznych, co będzie stopniowo ograniczać postęp procesu globalizacji.

Problem starzenia się społeczeństwa w krajach rozwiniętych ma wiele aspektów ekonomicznych ${ }^{78}$ i kilka kwestii odnoszących się do globalizacji. Starsi ludzie są zwykle mniej aktywnymi konsumentami, co ogranicza wzrost popytu krajowego i może skłaniać lokalne firmy do zwiększania eksportu towarów i/lub zaangażowania inwestycyjnego na rynkach zagranicznych. Nizsza dynamika wzrostu lub stagnacja krajowego zasobu osób aktywnych zawodowo wzmacnia tendencję do wzrostu płac i kosztów wytwarzania, co może obniżyć cenową konkurencyjność towarów na rynku globalnym. Narasta presja na uzupełnienie podaży siły roboczej przez napływ pracowników (i ich rodzin) z zagranicy (i/lub przez import towarów). Zwiększenie imigracji rodzi nowe problemy ekonomiczne, a przede wszystkim społeczne i polityczne. Rosnące wydatki z budzetu państwa na emerytury, infrastrukturę i opiekę nad starszymi ludźmi powodują, że często jest ograniczone wsparcie ze środków budzetowych dla wymagających dostosowania branż, firm i pracowników, mniej konkurencyjnych na rynku globalnym. Z wielu powodów długofalowe skutki starzenia się zachodnich społeczeństw mogą prowadzić do stopniowego osłabienia wzrostu gospodarczego (oraz innych efektów) w Europie i USA, a w konsekwencji do obniżenia pozycji tych krajów w gospodarce światowej. Możliwość realizacji takiego scenariusza będzie zależeć od intensywności procesu starzenia się ludności kraju, a przede wszystkim od zmian w polityce państw rozwiniętych wobec problemów demograficznych.

Narastające nierówności dochodowe i majątkowe są problemem globalnym, który dotyczy wszystkich grup krajów. Analiza wskaźnika Giniego w ostatnim trzydziestoleciu wskazuje na wzrost nierówności dochodowych (w ujęciu brutto) na świecie, przy czym był on największy w krajach transformujących gospodarki. W 2013 r. poziom tego wskaźnika na świecie wynosił średnio prawie 0,50 i już był zbliżony we wszystkich grupach krajów ${ }^{79}$. Od roku 2008 globalny wskaźnik Giniego ma tendencję wzrostową, co oznacza powiększanie się nierówności dochodowych w większości krajów świata. Systemy redystrybucji dochodów działają lepiej w krajach rozwiniętych, co pozwala w pewnym stopniu złagodzić skutki nierówności i zaspokoić podstawowe

78 Szerzej na ten temat patrz: R. Lee, Macroeconomics, Aging and Growth, [w:] Handbook of the Economics of Population Aging, red. J. Piggott, A. Woodland, Elsevier, Amsterdam 2016, s. 59-118; R. Lee, A. Mason, Cost of Aging, „Finance and Development” March 2017, s. 7-9.

79 I. Peters, M. Volwachsen, op.cit., s. 112, wykr. 1 i 2. W grupie pięciu krajów o najwyższych wskaźnikach (czyli o największej nierówności dochodowej) znalazły się: Lotwa $(0,60)$, Litwa $(0,56)$, Irlandia, Cypr, Portugalia $(0,55)$. Wskaźniki nierówności dochodowej byly najniższe w następujących krajach: Korea Południowa (0,32), Islandia $(0,37)$, Wenezuela $(0,38)$, Nowa Zelandia $(0,38)$, Sri Lanka $(0,41)$. 
potrzeby ludzi. Jednakże ogólnie nierówności dochodowe mogą hamować wzrost PKB od strony wielkości i jakości zasobów pracy, które stają się mniej liczne i mniej produktywne, a także od strony możliwości niepokojów społecznych, pogorszenia klimatu inwestycyjnego, narastania populizmu i protekcjonizmu.

Słaba dynamika wzrostu gospodarczego na świecie, rosnące nierówności dochodowe w większości krajów i pracooszczędny charakter postępu technicznego tworzą zestaw i układ czynników determinujących narastanie poważnych problemów ekonomicznych i społecznych w skali globalnej w przyszłości. Zdaniem World Economic Forum narastać będzie presja społeczna na realizację polityki ekonomicznej, której istotą jest oparcie wzrostu gospodarczego na szerszym włączeniu społeczeństwa (inclusive growth) w procesy rozwojowe $\mathrm{kraju}^{80}$. Będzie to oznaczać przesunięcie polityki rządów od starań o efektywne funkcjonowanie rynku w otwartej gospodarce do starań o uruchomienie inclusive growth w wyniku wdrożenia reform ekonomicznych prowadzących do aktywizacji produkcji oraz zatrudnienia, podnoszenia dochodów, poziomu życia i sprawiedliwości społecznej w kraju.

Potrzebę polityki państwa przeciwdziałającej nierówności i niesprawiedliwości w poszczególnych krajach i w skali światowej trudno byłoby przecenić. Jak stwierdził socjolog Ulrich Beck, niwelowanie nierówności na świecie staje się kluczowym problemem na przyszłość, gdyż z nierówności dochodowych i społecznych będzie tworzyć się szczególna cecha nowej sytuacji - wybuchowość społeczna i polityczna ${ }^{81}$.

Znaczenie czynników społecznych i demograficznych dla przebiegu globalizacji stopniowo zwiększa się w ostatnich latach, oddziałuje w sposób różnokierunkowy (stymulujący i destymulujący), wpływa na ten proces zarówno od strony ekonomicznej, jak i politycznej. W istniejących warunkach ekonomicznych ujawniło się wysoce krytyczne i przeciwne globalizacji nastawienie społeczne ${ }^{82}$. Może to implikować realizację przez państwo polityki skierowanej „do wewnątrz” kraju w celu uzyskania poparcia przez społeczeństwo, np. dla kandydatów w czasie wyborów.

\subsection{Czynniki polityczne}

Czynniki polityczne zmieniły oddziaływanie na przebieg procesu globalizacji w ostatnim dziesięcioleciu w porównaniu z wcześniejszymi dekadami drugiego etapu globalizacji. Wśród tego rodzaju czynników należy wymienić dwie podgrupy:

80 World Economic Forum, The Inchusive Growth and Development Report 2017, WEF, Geneva 2017, s. 1-6.

81 U. Beck, Metamorphosis of the World, Polity Press, Cambridge UK 2016, s. 197-198.

82 Potwierdzily to m.in. wyniki badania nastawienia i tonu artykułów w wiodacych czasopismach w USA i Wielkiej Brytanii, a także wystąpienia polityków. Por. P. Ghemawat, op.cit., s. 115. 
czynniki o charakterze ideologiczno-politycznym (polityka zagraniczna państw, polityka organizacji międzynarodowych, np. ONZ) oraz o charakterze polityki ekonomicznej (krajowej, międzynarodowej). Na drugim etapie globalizacji w latach 90. - zwłaszcza w krajach Europy Środkowej i Wschodniej oraz w Chinach - dokonaly się bardzo ważne zmiany polityczne, które uwolniły gospodarki z systemu centralnego planowania gospodarczego. Jednocześnie w wielu krajach została zapoczątkowana transformacja systemu ekonomicznego, prowadząca do tworzenia instytucji i mechanizmów gospodarki rynkowej, rozwoju sektora prywatnego, otwierania gospodarek na powiązania zewnętrzne, integracji regionalnej (przez rozszerzenie UE), uczestnictwa w międzynarodowych organizacjach ekonomicznych (WTO, Bank Swiatowy, MFW). Podobnie jak wcześniej państwa Zachodu, kraje transformujące gospodarki przyjęły (w różnym stopniu) neoliberalny kurs w polityce ekonomicznej, co polegało na usuwaniu przeszkód w rozwoju rynku i przedsiębiorstw prywatnych (deregulacja, prywatyzacja), niwelowaniu barier handlowych i rozszerzaniu dostępu dla zagranicznych towarów i czynników wytwórczych oraz zagranicznych firm, powiązaniu krajowego systemu finansowego $\mathrm{z}$ międzynarodowym rynkiem, wstąpieniu do organizacji o światowym zasięgu. Wielkie przemiany polityczne i ekonomiczne stworzyły przesłanki do uczestnictwa większej liczby krajów (transformujących gospodarki) w wymianie światowej i procesie globalizacji. Z jednej strony stało się to czynnikiem stymulującym postęp globalizacji, z drugiej zaś stworzyło dla wielu krajów możliwości rozwoju gospodarczego i społecznego dzięki aktywnemu uczestnictwu w globalizacji i zwiększaniu płynących z tego korzyści (przykładem tego są Chiny).

Perturbacje na rynkach finansowych i w gospodarce światowej związane z kryzysem 2008 + zapoczątkowały lub przyspieszyły zmiany w działaniu czynników politycznych. W ostatnim dziesięcioleciu sytuacja polityczna na świecie jest coraz bardziej niespokojna i niepewna. Narastają napięcia w stosunkach między państwami, trwają lokalne konflikty i zdarzają się akty terroryzmu, mają miejsce próby z bronią nuklearną, eksponowane są narodowe interesy partii rządzących i nowych, populistycznych przywódców, aktywizują się ruchy społecznościowe kontestujące globalizację. Klimat dla wielostronnej współpracy międzynarodowej pogarsza się, a polityczne przesłanki procesów integracyjnych ulegają osłabieniu (brexit, oddalanie się Turcji od UE). Kraje Europy Środkowej - zwłaszcza Polska - prowadzą działania polityczne trudne do zaakceptowania przez instytucje UE. Od wyników wyborów (prezydenckich i parlamentarnych) oraz od nowo przyjętego kursu politycznego będą zależeć zmiany w zagranicznej polityce ekonomicznej państw i w polityce międzynarodowej na świecie w najbliższych latach.

Kluczowe znaczenie dla sytuacji politycznej na świecie w przyszłości mieć będzie polityka USA. Jej nowe kierunki wytycza obecnie prezydent Donald Trump, który 
negatywnie ocenia skutki globalizacji dla gospodarki amerykańskiej i zamierza temu przeciwdziałac ${ }^{83}$. Zadeklarował on w polityce zagranicznej Stanów Zjednoczonych podejście nacjonalistyczne, transakcyjne, skupione na zapewnieniu wąskich, materialnych korzyści dla tego kraju - bez względu na implikacje dla liberalnego porządku na świecie ${ }^{84}$. Ze strony partnerów USA może to spowodować narastanie dystansu do amerykańskiej polityki i poszukiwanie alternatywnych rozwiązań czy układów dla zabezpieczenia swoich interesów. W sferze ekonomicznej na obecnym etapie polityki zagranicznej prezydenta Trumpa zakłada się zmianę podejścia do otwartego, liberalnego systemu handlu międzynarodowego, czego wyrazem może być silna krytyka porozumienia NAFTA, brak poparcia dla TTIP, zamiar odejścia od Partnerstwa Transpacyficznego i porozumień klimatycznych, możliwe restrykcje handlowe wobec Chin.

Obecna polityka Stanów Zjednoczonych jest zorientowana „do wewnątrz” tego kraju bardziej niż kiedykolwiek od czasu II wojny światowej ${ }^{85}$. Być może pod wplywem doradców i przywódców innych państw prezydent Trump wycofa się z takiej orientacji, a USA powrócą do swojej tradycyjnej polityki na arenie międzynarodowej w ramach obecnego systemu (chociaż może on ulec modyfikacji). Jeśli jednak nie wycofa się, to amerykańscy partnerzy na świecie będą musieli zapewnić sobie bezpieczeństwo i dobrobyt w sposób autonomiczny. Może to narazić USA i inne kraje na duże koszty płynące $z$ niestabilności globalnego systemu politycznego, z poszukiwania rozwiązań alternatywnych dla partnerstwa $z$ USA, a może nawet $\mathrm{z}$ retaliacji w stosunkach międzynarodowych. Niepewna sytuacja polityczna na świecie pogarsza klimat dla wymiany gospodarczej, a zwłaszcza dla przepływów ZIB, co ogranicza zaangażowanie firm na rynku globalnym, a w rezultacie może osłabić proces globalizacji.

W polityce ekonomicznej wielu krajów dokonują się zmiany zmierzające w podobnym kierunku. Kryzys 2008+ spowodował reakcję w polityce handlowej niektórych krajów, polegającą na zwiększeniu ochrony rynku krajowego przed napływem towarów z zagranicy i pasywizacją bilansu handlowego, jak też przed ograniczeniem popytu na rynku krajowym. Nie nastąpiło szerokie odchodzenie od ogólnych zasad WTO, ale wprowadzone w wielu krajach utrudnienia dla importu towarów stały się znaczącą przeszkodą dla rozwoju wymiany międzynarodowej. W latach 2008-2015 odnotowano ponad 3500 nowych utrudnień dla przywozu towarów z zagranicy, a zostały

83 F. IIu, M. Spence, Why Globalization Stalled and How to Restart It, „Foreign Affairs” July/August 2017, s. 55-59.

84 S.M. Patrick, Trump and World Order: The Return of Self-Help, „Foreign Affairs” March/April 2017, s. $52-57$.

85 R. Niblett, Liberalism in Retreat. The Demise of a Dream, „Foreign Affairs” January/February 2017, s. 17-24. 
one wprowadzone głównie przez Rosję (65 posunięć restrykcyjnych), Indie (55) oraz USA $(51)^{86}$. Wśród tego rodzaju instrumentów były bezpośrednie ograniczenia importu, dyskryminacja zagranicznych firm w zamówieniach publicznych, ograniczenia ilościowe, dodatkowe opłaty itp. Co istotne, takie posunięcia towarzyszyły innym utrudnieniom na rynku krajowym oraz publicznej dezaprobacie dla firm inwestujących za granicą, np. dla przenoszenia produkcji do krajów o niższych kosztach.

„Patriotyzm ekonomiczny” okazał się nośnym hasłem - np. w formie „Buy American" - kształtującym postawy krajowych nabywców. Zachęcanie do kupowania produktów wytwarzanych w kraju dotyczy nie tylko oferty handlowej, ale również wewnąt rzkorporacyjnego importu na rynek krajowy przez KTN o globalnych łańcuchach dostaw. Przenoszeniu produkcji za granicę przez KTN przeciwstawiają się niektóre partie polityczne w Europie Zachodniej, a przede wszystkim nowe władze w USA. Amerykańskie korporacje są obwiniane w macierzystym kraju o „wyprowadzenie" kapitału, miejsc pracy i dochodów, transfer wiedzy i technologii za granicę, unikanie opodatkowania i lekceważenie interesów obywateli. Prezydent Trump przygotowuje zestaw instrumentów mających zniechęcić amerykańskie KTN do offshoringu, a skłonić do produkcji w kraju i ewentualnie eksportowania towarów z USA do innych krajów. Mają temu służyć zmiany w systemie podatkowym (głównie obniżenie stawek), deregulacja w kilku dziedzinach gospodarki, dostawy taniej energii, a także renegocjacje umów handlowych z niektórymi krajami (np. z Chinami) oraz wzmocnienie ochrony pochodzącej z USA własności intelektualnej ${ }^{87}$. Za przykładem Stanów Zjednoczonych mogą pójść inne kraje, przy tym obwiniając globalizację za trudności w gospodarce krajowej.

Polityka ekonomiczna skierowana do przedsiębiorstw w gospodarce krajowej ewoluuje w długim okresie. Zasadnicza zmiana kursu takiej polityki prowadzi od liberalizacji wewnętrznej i zewnętrznej (deregulacja, prywatyzacja, usuwanie barier dla kooperacji i wymiany zagranicznej) do podnoszenia międzynarodowej konkurencyjności przedsiębiorstw, gałęzi i całej gospodarki krajowej. Rewolucja technologiczna wysunęła na plan pierwszy znaczenie informacji, wiedzy, nowych technologii oraz innowacji jako podstawy międzynarodowej konkurencyjności ekonomicznej. W polityce państwa nastąpily zmiany, które polegały na wspieraniu rozwoju gospodarki opartej na wiedzy dzięki zwiększaniu nakładów na działalność B+R,

86 G.C. Hufbauer, E. Jung, Why Has Trade stopped Growing? Not Much liberalization and Lots of MicroProtection, „Trade and Investment Policy Watch”, Peterson Institute for International Economics, March 23, 2016, https://piie.com/blogs/trade-investment-policy-watch/why-has-trade-stopped-growing-not-muchliberalization-and-lots [dostęp 27.04.2017].

87 J. Paulson, Trump and the Economy. How to Jump-Start Growth, „Foreign Affairs” March/April 2017, s. $8-11$. 
podnoszeniu zaawansowania technologicznego zasobów i zdolności wytwórczych, ułatwianiu transferu technologii oraz dyfuzji wiedzy, technologii, innowacji w kraju. Ponadgraniczne powiązania podmiotów krajowych (firmy, uczelnie, ośrodki B+R) oraz zagranicznych (korporacyjne ośrodki badawcze i filie produkcyjne) uczestniczących w działalności innowacyjnej w ramach NSI są faktem, a realizowana obecnie przez państwo polityka innowacyjna musi to uwzględniacíc ${ }^{88}$. W konsekwencji polityka innowacyjna znacząco wpływa na działalność B+R i międzynarodową konkurencyjność lokalnych podmiotów (częściowo też zagranicznych) oraz ich uczestnictwo w globalizacji.

Reasumując, od czasu kryzysu 2008-2009 działanie czynników globalizacji zmienia się, co może prowadzić do ewolucji procesu globalizacji. Na drugim etapie globalizacji kierunki działania czynników - przy różnej ich intensywności - były ogólnie zbieżne i wspierające postęp omawianego procesu. W obecnym przebiegu globalizacji działanie czynników technologicznych, ekonomicznych i częściowo społecznych w zasadzie wspiera postęp globalizacji, chociaż nie jest to działanie silne. Natomiast polityka państwa stopniowo staje się czynnikiem ograniczającym ten proces, zarówno w sposób bezpośredni, jak i pośredni - wpływając na działanie innych czynników. W takim układzie polityka państwa - zwłaszcza ze strony krajów będących globalnymi potęgami gospodarczymi - może w dużym stopniu determinować dalszy przebieg procesu globalizacji.

\section{Oznaki metamorfozy procesu globalizacji}

Dotychczasowe rozważania wskazują, że oznak utrwalających się przemian w procesie globalizacji należy poszukiwać w przepływach towarów i czynników, w działających czynnikach i mechanizmach integrowania biznesu ponad granicami państw oraz w działalności podmiotów - głównie KTN i państw narodowych. Ważnym tłem tych przemian jest stan aktywności i ewolucja struktury produkcyjnej w gospodarce światowej. Oprócz zaakcentowania najważniejszych dotychczasowych tendencji zostaną uwzględnione elementy przewidywań w celu dokonania oceny trwałości tych tendencji na przyszłość. Istotę przemian zachodzących w procesie globalizacji dobrze oddaje termin „metamorfoza”, który sugeruje przekształcenia w ramach

\footnotetext{
88 Szerzej na temat uczestnictwa ośrodków badawczych i filii KTN w narodowym systemie innowacyjnym (NSI) goszczącego je kraju patrz w publikacji: A. Zorska, Rozwój i umiędzynarodowienie innowacyjności w otwartej gospodarce. Implikacje dla polityki innowacyjnej państwa, [w:] Polityka publiczna we wspótczesnym państwie, red. J. Osiński, Oficyna Wydawnicza SGII, Warszawa 2014, s. 230-243.
} 
procesu - wraz z kompleksem jego specyficznych czynników, mechanizmów, podmiotów - które mogą prowadzić do nowego etapu jego rozwoju.

Międzynarodowa wymiana handlowa i inwestycyjna w okresie 2008+ cechowała się niską dynamiką oraz zmianami w strukturach geograficznej i towarowej. Wskazują one na stosunkowo szybko rosnące znaczenie Chin oraz innych krajów rozwijających się jako uczestników przepływów gospodarczych na świecie. Tendencje te mogą się utrwalać, gdyż niska aktywność gospodarcza i brak wzrostu wydajności mogą skutkować - przy dużej złożoności oddziaływań - utrzymywaniem się niskiej dynamiki wymiany międzynarodowej. Badacze przewidują, że rozwój gospodarki światowej do roku 2030 prawdopodobnie będzie cechować się niską dynamiką ${ }^{89}$ W takich warunkach zintensyfikuje się rywalizacja na rynku globalnym. Sukcesy będą odnosić przedsiębiorstwa i gospodarki bardziej konkurencyjne, a takimi są i przypuszczalnie pozostaną Chiny, Indie i niektóre inne kraje rozwijające się. Rosnący zbyt na rynkach zagranicznych i krajowych przyczyni się do dynamizacji wzrostu gospodarczego oraz większego znaczenia krajów rozwijających się w globalnej gospodarce. Na tle tzw. nowych potęg gospodarczych - grupy krajów z Azji i Ameryki Lacińskiej - wyraźnie obniża się pozycja ekonomiczna UE na świecie ${ }^{90}$. Badacze z Center for European Policy Studies (Bruksela) przewidują wzrost udziału Chin do 25\% i Indii do $10 \%$ światowego PKB w 2030 r., co tworzy łącznie 35\% globalnego produktu. Udział krajów Triady przypuszczalnie wyniesie w tym czasie $37 \%$, co oznacza jego obniżenie się o 10 pkt. proc. w latach 2010-2030 $0^{91}$. Wskazuje to, że globalne centrum aktywności gospodarczej i globalizacji przesunie się poza kraje Triady, a jego „rdzeniem” staną się Chiny i częściowo Indie. Jednakże zdaniem amerykańskich ekonomistów w następnych latach kraje te jeszcze nie będą w stanie dorównać USA pod względem poziomu rozwoju gospodarki, nauki, techniki, instytucji oraz pozycji politycznej ${ }^{92}$.

Pierwszą oznaką metamorfozy globalizacji jest więc przesuwanie się nurtu tego procesu ku Chinom (częściowo też ku innym krajom azjatyckim), które starają się dorównać pozycji USA w gospodarce światowej. Być może w dalszej perspektywie wyłoni się nowe, ścisłe centrum procesu globalizacji - Diada, w której składzie

89 Taką opinię wyrażają autorzy prezentujący wyniki badań nad przyszłym rozwojem i zmianami w gospodarce światowej: N. Crafts, Wither Economic Growth?, „Finance and Development” March 2017, s. 3-6 oraz M. Barslund, D. Gros, Europe's Place in the Global Economy - What Does the Last Half Century Suggest for the Future?, „Intereconomics” No. 1, 2016, s. 5-11. Uwaga: na temat długofalowej dynamiki wzrostu światowego handlu brak ilościowych prognoz, sa tylko ogólne opinie.

90 Zdaniem badaczy powodem tego jest ,starzenie się" kontynentu europejskiego oraz niedostateczne reformy instytucjonalne i ekonomiczne w UE. Patrz R. Kappel, The Challenge to Europe: Regional Powers and the Shifting of the Global Order, „Intereconomics” No. 5, 2011, s. 275-286.

91 M. Barslund, D. Gros, op.cit., s. 7, rys. 5 oraz obliczenia własne.

92 Taka opinię w cytowanych artykułach wyrażają ekonomiści amerykańscy: J. Paulson, M. Spence, F. Iu, P. Ghemawat, Th. Hout. 
znajdą się USA i Chiny. Prawdopodobnie wokół tych dwóch filarów ekonomicznych skupią się inne kraje, ale niekoniecznie według obecnego podziału na rozwinięte i rozwijające się.

Duże znaczenie dla przeobrażeń w globalizacji mają czynniki kształtujące ten proces. W stosunku do drugiego etapu globalizacji w okresie 2008+ postępują zmiany w pracy i wzajemnych oddziaływaniach tych czynników, przy czym relatywnie osłabiło się działanie czynników technologicznych, a wzrasta znaczenie czynników politycznych. Pomimo stymulujących uwarunkowań od strony rewolucji technologicznej ostatnie dziesięciolecie było okresem raczej niesprzyjającym wdrażaniu nowych technologii w biznesie, głównie w następstwie destymuluą̨cego wpływu kryzysu i spowolnienia gospodarczego, zwłaszcza w krajach rozwiniętych. Oddziaływanie czynników technologicznych na dalszy przebieg procesu globalizacji wymaga naświetlenia.

Przewidywania dotyczące postępu naukowo-technicznego w dłuższym okresie są obarczone znaczną dozą niepewności, głównie z powodu nieprzewidywalności tego postępu. Zdaniem specjalistów rewolucja cyfrowa jest obecnie w fazie rozwoju (nie dojrzałości), toteż na bazie technologii cyfrowych można oczekiwać stworzenia wielu innowacji radykalnych (zmieniających branże przemysłu i usług) oraz przyrostowych (ulepszających produkty, procesy) w przyszłości. Duży postęp dokona się również w innych dziedzinach nowych technologii, zwłaszcza w biotechnologiach, inżynierii genetycznej, syntetycznych materiałach i paliwach itd. Zdaniem R. Baldwina największe znaczenie ekonomiczne w najbliższych latach nadal będą mieć technologie informacyjne (oraz bazujące na nich specyficzne innowacje), które usprawnią i obniżą koszty bezpośrednich kontaktów specjalistów (face-to-face), podniosą bezpieczeństwo transferu danych i usprawnią przepływy niejawnej wiedzy, technologii, innowacji w sieciach biznesowych ${ }^{93}$. Powstaną lepsze warunki do tworzenia nowej wiedzy przez partnerów różnych projektów w sposób wyspecjalizowany, ale raczej nie w produkcji materialnej (jak np. części i podzespoły), lecz głównie w wytwarzaniu produktów niematerialnych. Chodzi o specjalistyczne usługi w procesach badawczo-innowacyjnych i/lub w technologicznie zaawansowanym podwykonawstwie (np. 2-3 operacje $z$ zakresu inżynierii genetycznej), które $z$ powodu wąskiej specjalizacji i wysoce specjalistycznych kompetencji muszą być realizowane w sposób kooperatywny. Mogą jednak nasilać się niekorzystne dla offshoringu zjawiska, jak np. trudności i koszty koordynacji silnie rozproszonych łańcuchów tworzenia wartości, malejące różnice płac w różnych krajach, deficyt specjalistycznych kadr, restrykcje w krajach macierzystych KTN i w krajach goszczących.

93 R. Baldwin, op.cit., s. 196-206. 
Postęp w zakresie technologii cyfrowych będzie wymuszał zmiany w funkcjonowaniu i działalności przedsiębiorstw (KTN). Zasygnalizowane zmiany będą pogłębiać specjalizację wewnątrz działań tworzących wartość dodaną, stymulować dalsze rozczłonkowanie łańcuchów wartości przedsiębiorstw i geograficzne rozproszenie działań realizujących je jednostek/podmiotów w wielu krajach. Bardziej intensywne, biznesowe zastosowanie najnowszych technologii informacyjnych w ponadgranicznych sieciach produkcyjno-handlowych KTN może prowadzić do rozwijania globalnego offshoringu. Byłby to wysoce zaawansowany technologicznie i specjalistyczny offshoring, wymagający mniej przepływu towarów, a więcej transferu danych, informacji wiedzy, np. służącej do produkcji z użyciem drukarek 3D. Czy będą dobre warunki polityczne do jego realizacji?

Drugą oznaką metamorfozy globalizacji, dokonującej się pod wpływem czynników technologicznych, mogą być zmiany polegające na pogłębianiu się specjalizacji w ramach łańcuchów tworzenia wartości przedsiębiorstw, rosnącym rozczłonkowaniu i rozproszeniu geograficznym produkcji niematerialnej. Przenoszenie wykonania wąskich i wysoce specjalistycznych zadań badawczych oraz zaawansowanej technologicznie produkcji do zagranicznych lokalizacji będzie skierowane do krajów posiadających odpowiednie zasoby i zdolności technologiczne, niekoniecznie do krajów rozwiniętych. Będzie to wpływać na zmiany struktur handlu i inwestycji na korzyść krajów posiadających kadry utalentowanych badaczy oraz najbardziej nowoczesne zdolności badawcze i wytwórcze.

Znaczenie czynników ekonomicznych dla przebiegu globalizacji będzie związane z odbudową tempa wzrostu i zmianami struktury PKB w dużych gospodarkach krajowych na świecie. Przyspieszenie dynamiki ekonomicznej (np. dzięki rosnącym dochodom ludności) umożliwi lokalnym przedsiębiorstwom zwiększenie produkcji i zbytu na rynek krajowy, pozwoli zwiększyć nakłady na innowacyjność, stworzy „poligon doświadczalny" dla nowych produktów, podniesie konkurencyjność na rynku globalnym. Aktywność biznesowa i ekspansja zagraniczna krajowych przedsiębiorstw będzie częściowo zależeć od „wkładu” państwa w modernizację zasobów, zdolności wytwórczych oraz infrastruktury w kraju.

Jeśli chodzi o poszczególne kraje, to rozwiązanie problemów z odbudową dynamiki wzrostu i wydajności w gospodarkach krajów rozwiniętych będzie zależeć od reform ekonomicznych, które zaowocują wzrostem popytu i PKB, a następnie umożliwią silne pobudzenie innowacyjności. Pomimo dotychczasowych sukcesów niepokój budzi przyszłość gospodarki Chin z powodu obniżającego się tempa wzrostu oraz kumulowania się wewnętrznych problemów ekonomicznych. Poza Chinami rozwój gospodarek innych krajów BRICS zależy od reform gospodarczych oraz instytucjonalnych. Niepokojący jest słaby wzrost gospodarczy, słabnąca innowacyjność 
i konkurencyjność międzynarodowa, trudne problemy społeczne (m.in. na tle napływu uchodźców) i brak postępu w integracji regionalnej Unii Europejskiej. Europa Środkowa mogłaby umocnić pozycję w skali regionalnej i globalnej, gdyby - uczestnicząc w reformach UE - silnie zwiększyła innowacyjność krajowych przedsiębiorstw. Ożywienie koniunktury w USA może pozytywnie wpłynąć na dynamikę gospodarki światowej, ale nie musi być znaczące dla globalizacji, jeśli zostaną zrealizowane zapowiedzi prezydenta D. Trumpa dotyczące protekcjonizmu handlowego. Na rozwój korzystnych tendencji ekonomicznych na świecie będą wpływać zmiany na globalnym rynku finansowym, a także stan bezpieczeństwa międzynarodowego.

Jeśli nie wydarzy się wojna handlowa na świecie (np. w wyniku protekcjonizmu i akcji odwetowych), to można oczekiwać neutralnego wpływu czynników ekonomicznych na proces globalizacji. Są jednak poważne problemy o charakterze globalnym, czym powinny zająć się państwa, ich grupy czy ugrupowania (np. G-7, G-20, UE) i organizacje międzynarodowe. Czynniki ekonomiczne przypuszczalnie nie dadzą bezpośrednich impulsów do metamorfozy procesu globalizacji w najbliższych latach. Raczej będzie to wpływ pośredni, dokonujący się przez interakcje z innymi czynnikami.

Czynniki społeczne i demograficzne stają się siłą o rosnącym znaczeniu, która w przyszłości może oddziaływać na procesy polityczne i ekonomiczne, a w konsekwencji na przebieg globalizacji. W warunkach niekorzystnych trendów demograficznych w krajach rozwiniętych otwarcie gospodarek daje możliwość uzupełnienia krajowej podaży importem towarów i czynników wytwórczych (zwłaszcza siły roboczej), a w rezultacie utrzymania wzrostu ekonomicznego i dobrobytu zamożnych, lecz starzejących się społeczeństw. Jednakże ze względu na różnice kulturowe i inne odmienność „obcego” elementu jest trudna do zaakceptowania. W krajach rozwijających się ekonomicznie i mających „młodszą" strukturę demograficzną sytuacja jest inna. Rosnące dochody, zmiany modelu życia, edukacja, potrzeba ochrony przyrody, odpowiedzialność społeczna itd. kształtują postawy prospołeczne. Narasta sprzeciw wobec wielkich różnic dochodowych i majątkowych $z$ jednej strony, a $z$ drugiej - przeciwko bezrobociu, spadkowi płacy realnej, ubóstwu, wykluczeniu, tragediom konfliktów i katastrof. Te niekorzystne zjawiska są częściowo skutkiem przemian rynkowych zachodzących w dobie globalizacji, ale bardziej skutkiem obecnej rewolucji technologicznej.

Powstaną lub zaostrzą się problemy społeczne wynikające z pracooszczędnego charakteru nowych technologii (rozwój automatyzacji, robotyzacji) oraz z restrukturyzacji gospodarki ${ }^{94}$. Następstwem „ali" szerokiego wdrażania nowych technologii

94 Można podać następujący przyklad wplywu technologii informacyjnych na zatrudnienie w przedsiębiorstwie: gdy w 2012 r. firma Instagram została sprzedana Facebookowi, miała już około 30 mln klientów, 
cyfrowych może być wielki wzrost bezrobocia. Niestety, korzyści i koszty postępu dzielone są nierówno w społeczeństwie. Brak zatrudnienia i stałych dochodów z pracy dla milionów ludzi, skazanie ich na dorywczą pracę lub zasiłki społeczne wygeneruje jeszcze większe nierówności dochodowe oraz poczucie niesprawiedliwości i wykluczenia. Może to prowadzić do wybuchów protestów społecznych. Przeciwdziałanie takiej sytuacji wymaga większego zaangażowania państwa w prospołeczną politykę, obejmującą nie tylko rozwijanie bezpieczeństwa socjalnego, lecz również pomoc ludziom w zdobywaniu nowych kwalifikacji, tworzenie miejsc pracy, poprawę systemów edukacji i ochrony zdrowia itd. ${ }^{95}$ Zauważmy, że podobny niepokój społeczny może dodatkowo wzbudzić eksponowana przez R. Baldwina tendencja do rozwoju offshoringu usługowego, co jest bezpośrednio związane z procesem globalizacji.

Trzecią oznaką metamorfozy globalizacji stają się sprzeczności i konflikty społeczne mające miejsce wewnątrz poszczególnych krajów, a także między krajami - w istocie między społeczeństwami czy grupami społecznymi - odnoszącymi korzyści i ponoszącymi koszty wynikające nie tylko z globalizacji, lecz również - a może przede wszystkim - z postępu technologicznego. Może to doprowadzić do wielkich protestów, a nawet poważnych konfliktów. Obawy przed takim rozwojem sytuacji społecznej muszą skłonić państwa do łagodzenia napięć, a przede wszystkim do usuwania przyczyn niekorzystnych zjawisk. Implikuje to rosnącą presję na prospołeczne zmiany w polityce państwa.

Czynniki polityczne zmieniają działanie pod wpływem decyzji państw narodowych (ich władz), instytucji (np. partii politycznych) oraz organizacji międzynarodowych. Zmiany w polityce ekonomicznej państwa są zwykle pochodną nowych procesów, zjawisk czy wielkich wydarzeń (np. wybuch konfliktu) w sferach gospodarczej czy społecznej, w wymiarze krajowym, regionalnym i globalnym. Omawiane czynniki uruchomiły lub wsparły liberalizację ekonomiczną w wielu krajach oraz transformację systemową, co przyspieszyło rozwój globalizacji na drugim etapie tego procesu. W przyszłości czynniki polityczne mogą nabrać kluczowego znaczenia w postępie globalizacji - hamując ten proces - jeśli nie zmieni się obecne podejście państw do różnych problemów.

zatrudniając 13 pracowników. Kilka miesięcy wcześniej doszło do bankructwa znanej firmy Kodak, która w okresie największych sukcesów rynkowych zatrudniała 145 tys. pracowników. Szerzej na ten temat: Effect Today's Technology on Tomorrow's Jobs, „The Economist", http://www.economist.com/news/leaders/ 21594298-effect-todays-technology-tomorrows-jobs-will-be-immenseand-no-country-ready/comments?page- 4 [dostęp 29.05. 2017].

95 Szerzej na ten temat w raporcie ONZ: Leaving No One Behind: the Imperative of Inclusive Development. Report of the World Situation 2016, UN, New York 2016, s. 28-31, 136-139, http://www.un.org/esa/socdev/ rwss/2016/full-report.pdf [dostęp 26.05.2017]. 
Zmiany zarysowane w punkcie 2.4 wskazują, że zapoczątkowana została reorientacja polityki państwa w krajach rozwiniętych - głównie w USA - „do wewnątrz” kraju. Priorytetem staje się rozwiązanie krajowych problemów ekonomicznych, społecznych i politycznych przez częściowe utrudnienie wymiany i współpracy międzynarodowej oraz wymuszenie dostosowań ze strony i kosztem podmiotów w otoczeniu globalnym. Przejawem takiego podejścia jest narastający w krajach rozwiniętych protekcjonizm handlowy, a jeszcze bardziej jego zapowiedzi w przyszłości. Przypuszczalnie ograniczenia będą skierowane przede wszystkim do przedsiębiorstw, ich zmian lokalizacyjnych oraz przepływów materialnych i niematerialnych, związanych z przenoszeniem za granicę produkcji, miejsc pracy, dochodów, nowych technologii oraz rozliczeń podatkowych. Takie ograniczenia rozważają niektóre kraje rozwinięte w UE, a przede wszystkim Stany Zjednoczone. Również komercyjny transfer wiedzy i nowych technologii przez KTN do innych krajów może być pozbawiony różnego rodzaju subsydiowania przyznanego na prowadzenie prac $\mathrm{B}+\mathrm{R}, \mathrm{z}$ intencją wykorzystania wyników badań w gospodarce macierzystej. Instrumenty polityki o charakterze restrykcyjnym mogą być różne, a powstają nowe, „wymykające się" porozumieniom handlowym w wymiarze regionalnym i globalnym. Zwiększa się niepewność i ryzyko ekonomiczne dla transakcji i kontraktów przedsiębiorstw, a jednocześnie pogarsza się klimat polityczny i bezpieczeństwo międzynarodowe.

Czwartą oznaką zachodzącej metamorfozy globalizacji jest reorientacja i waloryzacja znaczenia czynników politycznych kształtujących ten proces. Reorientacja jest związana ze zmianą kierunku działania omawianych czynników, które ewoluują od wspierającego do ograniczającego wpływu na proces globalizacji. W wielu krajach jest deklarowane polityczne i ekonomiczne wsparcie dla rozwoju gospodarki krajowej, a nie światowej. Waloryzacja polega na tym, że wzrasta znaczenie czynników politycznych w dalszym przebiegu globalizacji. Jest to wynikiem zastosowania obecnie - i przypuszczalnie w przyszłości - instrumentów polityki państwa odnoszących się bezpośrednio do wymiany i biznesu w skali międzynarodowej (np. offshoringu) oraz instrumentów działających pośrednio, tzn. w obszarach innych czynników (np. technologicznych, ekonomicznych, społecznych),

Kolejną strefą zmian dokonujących się w globalizacji jest przesunięcie w grupie podmiotów biorących udział w tym procesie. Na drugim etapie globalizacji nastąpiła erozja zdolności państwa do oddziaływania na procesy ekonomiczne, co było konsekwencją liberalizacji działalności gospodarczej oraz otwarcia gospodarek na przepływy i powiązania ponadgraniczne. Silnie rozwinęła się oraz zwiększyła znaczenie globalna ekspansja KTN i ich pozycja ekonomiczna na świecie, a korporacje osiągnęły wielkie korzyści z penetracji rynku globalnego. Negatywne skutki konkurencji ze strony KTN dla lokalnych firm oraz penetracji goszczących gospodarek 
spowodowały zmianę podejścia państw do działalności obcych KTN, lokowania ich ZIB i filii zagranicznych. Obecnie KTN są w trudniejszej sytuacji na rynkach zagranicznych, co będzie wymagać od nich zmian w strukturach organizacji, strategiach, kierunkach ekspansji zagranicznej. Bezpieczniejsze dla korporacji może okazać się większe zaangażowanie na rynku macierzystym. W skutek zmiany postrzegania działalności KTN nie ma zgody państwa na ich nieuczciwe praktyki biznesowe. Do akcji przeciwko niepożądanym praktykom KTN włączają się też organizacje międzynarodowe, co zwiększa szanse na ukrócenie takich praktyk, np. unikania opodatkowania. Przypuszczalnie korporacje zmienią strategie na rynku globalnym oraz taktykę wobec państw i ich polityki.

Piątą oznakę metamorfozy globalizacji tworzą przesunięcia w grupie podmiotów kształtujących przebieg tego procesu, co wyraża się ograniczeniem ekspansji zagranicznej i osłabieniem pozycji KTN wobec państw narodowych oraz zmianą charakteru relacji tych grup podmiotów na bardziej konfrontacyjne.

Przedstawione zmiany wpływu różnych czynników na przebieg globalizacji kumulują się w ewolucji mechanizmów tego procesu. Zachodzące zmiany implikują słabszą pracę mechanizmów rynkowego i korporacyjnego w procesie integracji globalnej, a większe znaczenie czynników instytucjonalnych, związanych z polityką ekonomiczną państw narodowych, mającą charakter quasi-autonomiczny (częściowo ograniczony przez umowy międzynarodowe i uczestnictwo w ugrupowaniach integracyjnych). Należy zauważyć, że w okresie 2008+ działalność organizacji międzynarodowych jest mniej aktywna i efektywna, jeśli nie liczyć dużej pomocy IMF i Banku Światowego w niwelowaniu skutków kryzysu finansowego. Interakcyjność czynników globalizacji powoduje, że wpływ polityki krajowej zwiększa się zarówno w sposób bezpośredni (np. w przypadku instrumentów polityki handlowej ograniczających import), jak i w sposób pośredni, kiedy instrumenty polityki są kierowane „do wewnątrz" kraju (np. na zmiany technologiczne, ekonomiczne, społeczne).

Szósta oznaka metamorfozy procesu globalizacji dotyczy funkcjonowania rynku światowego, którego mechanizmy obecnie nie są już uwalniane od interwencji państwa (liberalizowane), ale przeciwnie. Niektóre państwa wprowadzają instrumenty polityki częściowo ograniczającej powiązania rynku krajowego z rynkiem światowym, co de facto może prowadzić do ograniczenia rynkowych podstaw procesu globalizacji.

Znaczenie zachodzących przemian i przewartościowania czterech grup czynników kształtujących przebieg globalizacji dla zmiany charakterystyki tego procesu dostrzegli specjaliści. Zdaniem Iana Bremmera, specjalisty od ryzyka w biznesie międzynarodowym, minął okres akceptacji neoliberalnej polityki ekonomicznej przez większość państw na świecie. Teraz w krajach rozwijających i transformujących się 
(zwłaszcza w Chinach) państwo ustala inne zasady dostępu do rynku krajowego dla obcych firm, a sektor publiczny wspiera zagraniczną ekspansję krajowych przedsiębiorstw ${ }^{96}$. W rezultacie czynniki polityczne wpływają na przebieg i charakterystykę globalizacji. I. Bremmer wprowadził termin guarded globalization, co zgodnie z intencją autora można objaśnić jako "globalizacja strzeżona przez państwo" lub „globalizacja pod kontrolą państwa”.

\section{Podsumowanie}

Globalizacja ekonomiczna jest długofalowym, złożonym i wielowątkowym procesem, a na jej przebieg i charakterystykę wpływa wiele zmian dokonujących się w gospodarce (na wszystkich poziomach działalności), nauce i technice, populacji i społeczeństwie, jak też w instytucjach i polityce. Obecnie róźnego rodzaju zmiany dokonują się w warunkach spowolnienia ekonomicznego, a dynamizacji wzrostu gospodarek krajów i świata specjaliści nie spodziewają się w najbliższych latach. W takiej sytuacji nie można też oczekiwać przyspieszenia procesu globalizacji, a wiele wskazuje na możliwość jego zahamowania w przyszłości. Wysoko zagregowane dane o globalnych trendach zakrywają ważne przemiany strukturalne w gospodarce światowej, a najważniejszą z nich jest umacniająca się pozycja ekonomiczna Chin (jak też Indii oraz częściowo innych krajów rozwijających się) wobec USA i Unii Europejskiej oraz pozostałych krajów rozwiniętych. Dotyczy to przesunięcia udziałów w globalnym PKB, przepływach towarów oraz inwestycji bezpośrednich (ZIB), jak również znaczenia zachodnich i azjatyckich KTN na rynku globalnym.

Proces globalizacji ewoluuje pod wpływem wielkiej „fali” różnego rodzaju zmian, które można zebrać w cztery grupy czynników kształtujących globalizację, a są to: czynniki technologiczne, ekonomiczne, społeczno-demograficzne oraz polityczne. W warunkach spowolnienia gospodarczego i krzyżujących się tendencji zmian obecnie czynniki te cechują się wpływem o innej charakterystyce i intensywności niż na drugim etapie globalizacji, a w rezultacie prowadzi to do zapoczątkowania przemian w samym procesie. Przeprowadzona w pracy analiza pozwoliła ustalić sześć oznak obecnie zapoczątkowanej metamorfozy procesu globalizacji. Można je ująć następująco: 1) przesuwanie się centrum globalizacji od rozwiniętych krajów Triady ku Diadzie, tzn. USA i Chinom - dwóm wiodącym potęgom gospodarczym;

\footnotetext{
96 I. Bremmer, The New Rules of Globalization, „Harvard Business Review” January/February 2014, s. $103-105$.
} 
2) pogłębianie się offshoringu ku bardzicj wyspecjalizowanym i zaawansowanym technologicznie działaniom; 3) narastanie sprzeczności i konfliktów wewnątrz krajów oraz między krajami na tle korzyści i kosztów z globalizacji; 4) zwiększanie się znaczenia czynników politycznych na tle innych sił kształtujących zmiany globalizacji; 5) wzmocnienie pozycji państw narodowych wobec KTN i zmiana ich relacji na bardziej konfrontacyjne; 6) zmiany w mechanizmach globalizacji, polegające na umocnieniu mechanizmu instytucjonalnego (polityka państw i organizacji międzynarodowych) wobec mechanizmów rynkowego i korporacyjnego.

W skazane zmiany nasiliły się w okresie $2008+i$ sygnalizują przekształcenia w procesie globalizacji, jednak obecnie nie mają ",rewolucyjnego" wpływu na przebieg tego procesu. Czy ich działanie skumuluje się i umocni na tyle, ze metamorfoza będzie widoczna, a badacze ustalą charakterystykę nowego, trzeciego etapu globalizacji? Odpowiedź zależy przede wszystkim od tego, czy w przyszłości działanie czynników technologicznych i ekonomicznych będzie silniejsze niż społeczno-demograficznych, a przede wszystkim od czynników politycznych. Reorientacja polityki ekonomicznej państw rozwiniętych „do wewnątrz” kraju nabiera znaczenia, a jej protekcyjny charakter może ograniczyć postęp globalizacji, a może nawet dynamikę i efektywność wzrostu gospodarczego. Rządy państw staną przed trudnym wyborem: więcej społecznej sprawiedliwości (kosztem dynamiki gospodarczej) czy produktywności technologiczno-ekonomicznej (kosztem niepokojów społecznych). A może nauki społeczne i ekonomiczne opracują nowe koncepcje i rekomendacje na miarę XXIw. dla ekonomicznej roli państwa i jego polityki stymulującej rozwój gospodarek krajów i świata w dobie rewolucji technologicznej?

\section{Literatura}

Baldwin R., The Great Convergence. Information Technology and the New Globalization, The Belknap Press of Harvard University Press, Cambridge, Mass.-London 2016.

Barslund M., Gros D., Europe's Place in the Global Economy - What Does the Last Half Century Suggest for the Future?, „Intereconomics” No. 1, 2016.

Beck U., The Metamorphosis of the World, Polity Press, Cambridge-Malden 2016.

Bhagwati J., In Defence of Globalization, Oxford University Press, New York 2004.

Bremmer I., The New Rules of Globalization, „Harvard Business Review” January/February 2014.

Cornell University, INSEAD, WIPO, The Global Innovation Index 2016. Winning with Global Innovation, Ithaca-Geneva 2016. 
Crafts N., Wither Economic Growth?, „Finance and Development” March 2017.

Czech K., Znaczenie państw BRICS w międzynarodowym transferze kapitaku na przykladzie bezpośrednich inwestycji zagranicznych, [w:] Państwa grupy BRICS $i$ ich znaczenie we wspólczesnej gospodarce światowej, red. T. Sporek, K. Czech, Wydawnictwo UE w Katowicach, Katowice 2015.

Dicken P., Global Shift. Internationalization of Economic Activity, The Guilford Press, New York-London 1992.

Dunning J.H., The Globalization of Business. The Challenge of the 1990s, Routledge, London-New York 1993.

"The Economist", Effect Today's Technology on Tomorrow's Jobs, http://www.economist. com/news/leaders/21594298-effect-todays-technology-tomorrows-jobs-will-be-immenseand-no-country-ready/comments?page $=4$

Erber G., Fritsche U., Harms P.Ch., The Global Productivity Slowdown: Diagnosis, Causes and Remedies, „Intereconomics” No. 1, 2017.

Ghemawat P., Globalization in the Age of Trump, „Harvard Business Review” July/August 2017.

Ghemawat P., Altman S.A., Depth Index of Globalization and the Big Shift to Emerging Economies, IESE Business School-University of Navarra, Barcelona-New York 2013.

Ghemawat P., Hout Th., Can China's Companies Conquer the World? The Overlooked Importance of Corporate Power, „Foreign Affairs” March/April 2016.

Global 500, „Fortune” August 1, 2016.

Iu F., Spence M., Why Globalization Stalled and How to Restart It, „Foreign Affairs” July/ August 2017.

Hufbauer G.C., Jung E., Why Has Trade stopped Growing? Not Much liberalization and Lots of Micro-Protection, „Trade and Investment Policy Watch”, Peterson Institute for International Economics, March 23, 2016, https://piie.com/blogs/trade-investment-policy-watch/why-has-trade-stopped-growing-not-much-liberalization-and-lots

IMF, „World Economic Outlook” April 2017.

Iwanicz-Drozdowska M., Restrukturyzacja banków w Unii Europejskiej w czasie globalnego kryzysu finansowego, Oficyna Wydawnicza SGH, Warszawa 2015.

Jaruzelski B., Staack V., Schwartz K., The 2015 Global Innovation 1000: Innovation's New World Order, Strategy \&, PCW, October 2015,

http://www.strategyand.pwc.com/global/home/press/displays/innovations-new-world-order

Kappel R., The Challenge to Europe: Regional Powers and the Shifting of the Global Order, „Intereconomics” No. 5, 2011.

Khanna P., Rise of the Titans, „Foreign Policy” March/April 2016.

Kleer J., Specyfika państwa wspótczesnego. Państwo wspótczesne i mechanizmy jego destrukcji, [w:] Dokad zmierza Europa, red. J. Kleer, P. Szukalski, K. Prandecki, PAN, Komitet Prognoz „Polska 2000+”, Warszawa 2016. 
Kryzys gospodarczy 2008+ test dla stosowanej polityki. Metody przeciwdzialania i ich skuteczność, red. K. Żukrowska, Oficyna Wydawnicza SGII, Warszawa 2013.

Lee R., Macroeconomics, Aging and Growth, [w:] Handbook of the Economics of Population Aging, red. J. Piggott, A. Woodland, Elsevier, Amsterdam 2016.

Lee R., Mason A., Cost of Aging, „Finance and Development” March 2017.

Liberska B., Globalna architektura finansowa po kryzysie. Regulacje i wyzwania, [w:] Nowa architektura finansowa. W stronę bezpieczeństwa sektora bankowego, red. B. Liberska, Wydawnictwo UJ, Kraków 2016.

Malik R., Lokalizacja w offshoringu ustug, CeDeWu.pl, Warszawa 2016.

Mallaby S., Globalization Resets, „Finance and Development” December 2016.

Mazzucato M., The Entrepreneurial State. Debunking Public vs. Private Sector Myths, Anthem Press, London 2014.

McKinsey Global Institute, Financial Globalization; Retreat or Reset?, Mc Kinsey Company, March 2013.

Multinationals. The Retreat of the Global Company, „The Economist” January 28, 2017.

Niblett R., Liberalism in Retreat. The Demise of a Dream, „Foreign Affairs” January/February 2017.

Obstfeld M., Get on Track with Trade, „Finance and Development” December 2016.

Państwa grupy BRICS i ich znaczenie w gospodarce światowej, red. T. Sporek, K. Czech, Wydawnictwo UE w Katowicach, Katowice 2015.

Patrick S.M., Trump and World Order. The Return of Self-Help, „Foreign Affairs” March/ April 2017.

Paulson J., Trump and the Economy. How to Jump-Start Growth, „Foreign Affairs” March/ April 2017.

Pawlas I., Uczestnictwo państw BRICS w międzynarodowych obrotach towarowych, [w:] Państwa grupy BRICS i ich znaczenie we wspólczesnej gospodarce światowej, red. T. Sporek, K. Czech, Wydawnictwo UE w Katowicach, Katowice 2015.

PCW, Strategy \&, October 2015, http://www.strategyand.pwc.com/global/home/press/ displays/innovations- new-world-order

Peters II., Volwachsen M., Rising Income Inequality: Do Not Draw the Obvious Conclusions, „Intereconomics” No. 2, 2017.

Piketty T.H., Kapitat w XXI wieku, Wydawnictwo Krytyki Politycznej, Warszawa 2015.

Polityka publiczna we wspótczesnym państwie, red. J. Osiński, Oficyna Wydawnicza SGH, Warszawa 2014.

Poznańska K., Kraj K.M., Badania i rozwój w korporacjach transnarodowych. Organizacja - umiędzynarodowienie, Wydawnictwo Naukowe PWN, Warszawa 2015.

Quo Vadis. World Economy and Institutions at a Crossroads, red. M. Baldassarri, Palgrave-Macmillan, Houndmills-Basinstoke 2015. 
Rozhkov A.G., Smirnowa M.M., Rebiazina V.A., Customer Orientation in Emerging Markets: Concepts and Empirical Tests, [w:] Emerging Markets and the Future of the BRIC Nations, red. B.L. Kedia, K. Aceto, Edward Elgar Publ., Cheltenham-Northampton 2015.

Rugman A., Verbeke A., Greidanus N., Multinational Enterprises and Governments: An Analysis of New Trends, [w:] The Accountable Corporation. Business Government Relations, red. M.J. Epstein, K.O. Hanson, Praeger, Westport, Connecticut-London 2006.

Rymarczyk J. Biznes międzynarodowy, PWE, Warszawa 2012.

Stiglitz J.E., Cena nierówności. W jaki sposób dzisiejsze podzialy spoteczne zagrażają naszej przyszłości?, Wydawnictwo Krytyki Politycznej, Warszawa 2015.

Stiglitz J.E., Globalizacja, Wydawnictwo Naukowe PWN, Warszawa 2004.

Stiglitz J.E., Guzman M., Contemporary Issues in Macroeconomics: Lesson from the Crisis and Beyond, Palgrave-MacMillan, Basingstoke-New York 2016.

Stonehouse G., Hamill J., Campbell D., Purdie T., Globalizacja. Strategia i zarzadzanie, Felberg SJ-Wiley, Warszawa 2001.

UNCTAD, „Global Investment Trends Monitor” April 2017.

UNCTAD, World Investment Report 2010. Towards a New Generation of Investment Policies, UN-UNCTAD, New York-Geneva 2010.

UNCTAD, World Investment Report 2015. Reforming International Investment Governance, UN-UNCTAD, New York-Geneva 2016

UNCTAD, World Investment Report 2016. Investor Nationality: Policy Challenges, UN-UNCTAD, New York- Geneva 2016.

UNESCO, UNESCO Science Report. Towards 2030. Executive Summary, UNESCO Publ., Paris 2016.

Weresa M.A., Globalizacja działalności innowacyjnej we wspólczesnej gospodarce światowej, „Zeszyty Naukowe Kolegium Gospodarki Swiatowej SGII" czerwiec 2008.

World Bank, http://data.worldbank.org/indicator/NV.SRV.TETC.ZS

World Bank, World Development Report 2016: Digital Dividends, The World Bank Group, Washington 2016.

World Economic Forum, The Inclusive Growth and Development Report 2017, WEF, Geneva 2017.

WTO, International Trade Statistics 2015, WTO, Geneva 2016.

WTO, 2014 International Trade Statistics Yearbook, Vol. I, Geneva 2014.

WTO, 2015 International Trade Statistics Yearbook, Vol. I, Geneva 2015.

Yip G.S., Strategia globalna, PWE, Warszawa 2004.

Zorska A., Korporacje transnarodowe a suwerenność państwa. Kwestia relacji korporacje - państwo w dobie globalizacji, regionalizacji i rewolucji informacyjnej, [w:] Dokąd zmierza Europa: państwo - gospodarka - spokeczeństwo - finanse, red. J. Kleer, P. Szukalski, K. Prandecki, PAN, Komitet Prognoz „Polska 2000+”, Warszawa 2016. 
Zorska A., Korporacje transnarodowe. Przemiany, oddzialywania, wyzwania, PWE, Warszawa 2007.

Zorska A., Ku globalizacji? Przemiany w korporacjach transnarodowych i w gospodarce światowej, Wydawnictwo Naukowe PWN, Warszawa 1998.

Zorska A., Rozwój i umiędzynarodowienie innowacyjności w otwartej gospodarce. Implikacje dla polityki innowacyjnej państwa, [w:] Polityka publiczna we wspótczesnym państwie, red. J. Osiński, Oficyna Wydawnicza SGH, Warszawa 2014.

Zorska A., Umiędzynarodowienie prac $B+R$ w korporacjach transnarodowych oraz wplyw tego procesu na innowacyjność w krajach goszczacych, [w:] Innowacyjność $i$ konkurencyjność międzynarodowa. Nowe wyzwania dla przedsiębiorstw i polityki państwa, red. A. Janowska, R. Malik, R. Wosiek, Oficyna Wydawnicza SGH, Warszawa 2017.

https://knoema.com/atlas/ranks/High-technology-exports

http://unctad.org/en/PublicationsLibrary/webdiaeia2017d1_en.pdf

https://www.wto.org/english/res_e/booksp_e/wtr15-1_e.pdf

\section{Contemporary Globalization: Development of The Process, Factors Influencing It and Signs of its Metamorphosis}

The article aims at an analysis of changes in development of globalization which took place during the 2007-2008 crisis and the following years of the economic slowdown. The analysis is conducted against the background of the situation in the world economy and includes investigation of changes (dynamics and structures) in global flows of merchandise, exports of services and foreign direct investments. The structural transformation of global flows indicates the increasing share and role of China in the world economy. The significance of transnational corporations in the globalization process calls for portraying the evolution of their activity and relations with nation states and other groups of economic actors. Attention is drawn to changes in the set and forces of key globalization factors, including technological progress (in the age of information revolution), economic, social and demographic as well as political factors. The increasing impacts of evolving states' policies and socio-demographic situation on trends in the global economy are acknowledged. The transformation of globalization factors considerably affects the development and evolution (or metamorphosis) of the investigated process. Six signs of the initiated metamorphosis of globalization, which indicate possible intensification and direction of changes in the future development of the process, are discussed.

Keywords: world economy, globalization, globalization factors, transnational corporations, economic policy 


\section{La mondialisation contemporaine: évolution, facteurs et signes de la métamorphose du processus}

L'objectif de ce texte est d'analyser les changements intervenus dans le processus de mondialisation qui se sont produits pendant la crise mondiale de 2007-2008 et durant les années suivantes du ralentissement économique. Dans le contexte de la situation de l'économie mondiale, nous avons soumis à l'analyse les changements (de dynamique et de structure) des flux mondiaux de produits, de services et d'investissements directs étrangers. Les changements structurels indiquent une augmentation de la part et du rôle de la Chine dans l'économie mondiale. Vu l'importance des sociétés transnationales dans le processus de mondialisation, nous avons présenté l'évolution de leurs activités et de leurs relations avec les États-nations et d'autres groupes d'entités économiques. Nous avons présenté plus en détail les changements dans le système actuel et la puissance des principaux groupes de facteurs de la mondialisation que sont les facteurs technologiques (dont la révolution informationnelle), les facteurs économiques, sociaux et démographiques ainsi que les facteurs politiques. Nous avons établi l'influence croissante de l'évolution de la politique de l'État et de la situation sociodémographique sur les tendances de l'économie mondiale. Les changements concernant les facteurs de mondialisation sont d'une grande importance pour le cours ultérieur et la transformation (métamorphose) de ce processus. Nous avons décrit six signes de la métamorphose initiée de mondialisation qui indiquent la possibilité d'intensification et les directions des changements du processus étudié dans le futur.

Mots-clés: économie mondiale, mondialisation, facteurs de mondialisation, sociétés transnationales, politique économique

\section{Современная глобализация: ход процесса, его факторы и признаки метаморфоза}

Статья посвящена апализу изменений, которые произошли в процессе глобализации в период кризиса 2007-2008 годов и в последующие годы экономического спада. На фоне ситуации в мировой экономике были проанализированы изменения (динамики и структуры) глобальных потоков товаров, услуг и прямых иностраншых инвестиций. Структурные изменения указывают на увеличение доли и роли Китая в мировой экономике. Из-за важности транснациональных корпораций в процессе глобализации была представлена эволюция их деятельности и отношений с национальными 
государствами и другими группами экономических суб'ьектов. Внимание обращается на изменения в конфигурации и в силе ключевых групп факторов глобализации, включая технический прогресс (в эпоху информационпой революции), экономические, социалыные и демографические, а также политические факторы. Выявлено растущее влияние политики государства и социально-демографической ситуации на тенденции в мировой экономике. Изменения в сфере факторов глобализации значительно влияют на дальнейпую әволюцию и трансформацию (метаморфозу) исследуемого процесса. Рассматривается песть признаков начатой метаморфозы глобализации, которые указывают на возможность интенсификации и изменений исследуемого процесса в будущем.

Ключевые слова: мировая экономика, глобализация, факторы глобализации, транснациональные корпорации, экономическая политика 